\title{
Crop Upgrading Strategies and Modelling for Rainfed Cereals in a Semi-Arid Climate-A Review
}

\author{
Festo Richard Silungwe ${ }^{1,2, *}$, Frieder Graef ${ }^{1}$ (D), Sonoko Dorothea Bellingrath-Kimura ${ }^{1,2}$, \\ Siza Donald Tumbo ${ }^{3}$, Frederick Cassian Kahimba ${ }^{3}$ and Marcos Alberto Lana ${ }^{1,4}$ \\ 1 Leibniz Center for Agricultural Landscape Research (ZALF), Institute of Land Use Systems, Eberswalder \\ Straße, 84, 15374 Müncheberg, Germany; graef@zalf.de (F.G.); belks@zalf.de (S.D.B.-K.); \\ marcos.lana@zalf.de (M.A.L.) \\ 2 Faculty of Life Sciences, Humboldt Universität zu Berlin, Unter den Linden 6, 10099 Berlin, Germany \\ 3 Department of Engineering Sciences and Technology, Sokoine University of Agriculture, P.O. Box 3003, \\ CHUO KIKUU, Morogoro 3003, Tanzania; siza.tumbo@gmail.com (S.D.T.); \\ fredkahimba@suanent.ac.tz (F.C.K.) \\ 4 Crop. Production Ecology, Swedish University of Agricultural Sciences, Ulls väg 16, 75007 Uppsala, Sweden \\ * Correspondence: festo.richard@zalf.de; Tel.: +49-157-8482-5561
}

Received: 30 November 2017; Accepted: 16 March 2018; Published: 22 March 2018

\begin{abstract}
Spatiotemporal rainfall variability and low soil fertility are the primary crop production challenges facing poor farmers in semi-arid environments. However, there are few solutions for addressing these challenges. The literature provides several crop upgrading strategies (UPS) for improving crop yields, and biophysical models are used to simulate these strategies. However, the suitability of UPS is limited by systemization of their areas of application and the need to cope with the challenges faced by poor farmers. In this study, we reviewed 187 papers from peer-reviewed journals, conferences and reports that discuss UPS suitable for cereals and biophysical models used to assist in the selection of UPS in semi-arid areas. We found that four UPS were the most suitable, namely tied ridges, microdose fertilization, varying sowing dates, and field scattering. The DSSAT, APSIM and AquaCrop models adequately simulate these UPS. This work provides a systemization of crop UPS and models in semi-arid areas that can be applied by scientists and planners.
\end{abstract}

Keywords: The Agricultural Production Systems sIMulator (APSIM) software; AquaCrop; cereals; DSSAT; field scattering; food security; microdose fertilization; rainfall variability; tied ridges; upgrading strategies

\section{Introduction}

Food security refers to physical and economic access to sufficient, safe, and nutritious food that meets people's dietary requirements and food preferences for an active and healthy life [1,2]. Despite efforts from 1990 to 2012 to reduce the number of people suffering from hunger, the hungry population in Sub-Saharan African (SSA) countries was reduced by only $5 \%$. Millions of people in this region are still not able to meet food demand for their families due to land degradation, land use pressures, and climate change [3]. Other causes include population growth, poverty, weak institutions and infrastructure, high dependency on rainfed agriculture, unequal global trade relationships, and poor soil fertility [4-6]. There are also constraints related to the production value chain in general, food access [5,7] due to geographical locations and associated eating behaviors [8], socio-economic status [9], technology adoption [10,11], and sustainable production [12-14].

A total of $57 \%$ of the population in East African countries (Tanzania, Kenya, Uganda, Rwanda and Burundi) experienced food insecurity during 2015-2016, which is only a slight decrease from 
59\% during 1990-1992 [15]. The future status of food security of East African countries requires an integrated, long-term hunger mitigation plan to protect vulnerable households. The plan should involve governments in collaboration with civil society and international partners [16]. The responses may include the introduction of new technologies, extension of local expertise, and active involvement of the vulnerable households and communities suffering from hunger [16]. A previous study in Ethiopia emphasized the importance of investing in agricultural research of major staple foods to improve food security [11]. Kassie et al. [17] suggested the importance of formulating policies that target sustainable agricultural practices. These efforts can stimulate the adoption of crop upgrading strategies [18] and, thus, improve crop production and food security. Actually, enhancing agricultural production has improved food security and resulted in greater yields for many agricultural products since 2000 in Nigeria, Uganda, Tanzania and Kenya [19].

Food security upgrading strategies (UPS) can be defined as a set of good practices to secure food across local to regional food value chains [20]. They are designed to raise the sustainability of agricultural production of crops under rainfed conditions in semi-arid areas. Normally, UPS are adapted to a particular location depending on the local conditions of the soil, weather, culture, and socio-economic status. The UPS that enhance crop production include farm water ponds [21,22], irrigation [23,24], mulching [25,26], tied ridges [27,28], field scattering and shifting of planting/sowing dates $[29,30]$. While UPS are useful in enhancing agricultural production in general; their impacts are more visible for poor smallholder farmers who have a limited capacity to obtain the inputs for their farms such as irrigation and soil nutrients. The process of designing the UPS and testing them for adoption in different environments is the first step of a continuous process involving the creation and diffusion of new knowledge. There is a strong negative relationship between the number of food-deficient households and innovations in their farming practices [31], meaning that the households with the lowest food security are the ones adopting the fewest UPS. Encouraging farmers to use affordable UPS is vital for increasing harvests and reducing hunger in general. However, there is limited understanding of the roles that different UPS can play in securing harvests for farms that are limited by high rainfall variability and poor soil nutrients. Modelling approaches can provide such understanding, leading to recommendations for the implementation of UPS in different areas.

To understand crop production and associated management strategies at the local level and to expand the results to obtain an overview at the regional level, software crop simulation models such as Decision Support System for Agrotechnology Transfer (DSSAT) are useful [32]. Models can consider the interaction between UPS and weather parameters (such as rainfall and temperature) $[24,33,34]$. Thus, crop models are useful tools for researchers, academics, scientists, extension educators, policymakers, and planners in supporting the implementation and evaluation of the sustainability of UPS $[35,36]$. Models are very useful as they can provide prior sensitive information to reduce the risk of crop failure in rainfed cereal production systems. However, there is limited systemization of the information gathered on biophysical models that can be used to model the UPS that secure the optimum possible harvest of cereals under limited rainfall and soil nutrient conditions.

The objectives of this review were to (i) collect and systemize the scientific results on the performance of different UPS in reducing the risks related to rainfed cereal production in semi-arid environments; (ii) identify the biophysical models used to study selected UPS; and (iii) evaluate the strengths and limitations of the models in enhancing rainfed cereal production.

\section{Materials and Methods}

We collected papers from different literature repositories that describe the roles of upgrading strategies in the production of cereals (Table 1). The search keywords that were used and the examples of combinations are presented in Table 1 . The papers were screened in succession starting from a global context, then in arid and semi-arid climate countries and finally to the topic of this study. A total of 187 papers were relevant to this review from more than 1000 papers. The papers covered broadly the roles of UPS for cereal production in arid and semi-arid regions. In addition, the papers described the 
usefulness of modelling UPS for enhancing cereal production under low and highly variable rainfall and poor soil fertility conditions.

Table 1. Keywords and some of the combinations used to search the literature in the Web of Science, Directory of Open Access Journals (DOAJ), Google Scholar and ResearchGate.

\begin{tabular}{ll}
\hline Keywords & Combinations Used \\
\hline Upgrading strategies & Upgrading strategies for cereals \\
Cereals & Cereal crop management \\
Crop management & Rainfall in arid and semi-arid \\
Arid & Drought and harvest risk \\
Semi-arid & Adoption of crop management \\
Modelling & Spatiotemporal rainfall variability \\
Rainfall variability & Spatial plot distribution \\
Drought & Modelling tied ridges \\
Adoption & Food security and hunger for poor farmers \\
Food security & Food security in semi-arid areas \\
Climate change & Crop management strategies \\
Hydrology & Temporal rainfall variability \\
Tied ridges & Spatiotemporal rainfall variability in semi-arid areas \\
Planting dates & Crop management strategies for rainfall variability \\
Agricultural water & Crop management in poor soils \\
Spatiotemporal & Fertilizer management in drought areas \\
Spatial & Crop management strategies for poor farmers \\
Temporal & Spatiotemporal rainfall variability and crop yield \\
Plot scattering & Modelling of crop management \\
Microdose fertilization & Biophysical models for cereals in arid and semi-arid \\
Hunger & Rainfall variability and harvest risk of cereals \\
Risk & Simulation of cereals growth in semi-arid \\
Harvest Soil fertility & Arid-semi-maize-rainfall-variability-management-yield \\
\hline
\end{tabular}

The other conditions for the inclusion of papers in this review were the following:

i. $\quad$ Peer-reviewed articles on crop UPS and modelling in English published in 1990 and after. The UPS that were included were categorized as rainwater harvesting, soil moisture conservation, means of water application and productivity, nutrient addition to the soil, soil conservation, drought coping measures and measurements of rainfall variability.

ii. Reports with qualitative or quantitative empirical findings and perceptions and views discussed in relation to UPS and modelling.

iii. Conference proceedings papers related to UPS and modelling.

All the UPS identified in the selected papers were ranked according to importance, affordability, possibility, and effectiveness (Table 2). The authors arbitrarily defined these criteria in terms of UPS adequacy to address the rainfall variability and soil fertility conditions faced by farmers in semi-arid areas.

The constraints categories for the UPS were scored by six experts, ranging from 1 (highest constraining potential), 2 (medium constraining potential) to 3 (lowest constraining potential). These experts were familiar with UPS and were capable of making informed judgements about them. Using the experts' results, the constraint with highest scores was regarded as having the least constraining potential. The authors of this study then scored the UPS using the scores given by the experts. The UPS with the highest efficiency in overcoming the stated constraint in each criterion as judged by expert scores was given a score of 3 , the medium efficient was given a score of 2 and the least efficient was given a score of 1 . If half or more of the six experts gave a score of 3 to the constraint (i.e., expert one score $=3$, expert two score $=3$, expert three score $=1$, expert 4 score $=3$, expert 5 score $=2$, expert 6 score $=1$ ) then we picked 3 as a score. If the scores tied, for instance, three experts gave a score 
of 3 and two experts gave a score of 2, then we picked the highest score, which is 3 . Similarly, if two experts each gave similar scores we picked the highest score of the three given (i.e., two experts gave 1 , the other two gave a score of 2 and the other gave a score of 3 , then we picked 3 ). For example, for the criterion "importance" the constraint social acceptance was given a score of 1 because four experts gave a score of 1 , for constraint "labor" the score was 2 because three out of six experts gave a score of 2 and for constraint "sustainability" the score was 2 since four experts gave a score of 2 . In the next step, all constraints of a given criterion were averaged, producing suitability scores ranging from 1 to 3 , with 3 being the highest suitability, while 1 means low suitability. Finally, all criteria scores for a given UPS were averaged to form a final score.

Table 2. Four criteria used to select the most suitable upgrading strategies in semi-arid areas.

\begin{tabular}{|c|c|c|c|}
\hline Criteria & Criteria Definition & Constraints & Constraint Definition (Questions) \\
\hline Importance & $\begin{array}{l}\text { It significantly improves production in } \\
\text { semi-arid environments under } \\
\text { production constraints, has high social } \\
\text { acceptance, is easy to implement and is } \\
\text { sustainable }\end{array}$ & $\begin{array}{l}\text { Social acceptance } \\
\text { Labor } \\
\text { Sustainability } \\
\text { Environment } \\
\text { Rainfall variability } \\
\text { Soil fertility } \\
\text { Land availability } \\
\text { Productivity }\end{array}$ & $\begin{array}{l}\text { Is it likely to be adopted by most people? } \\
\text { Does it involve much labor to implement? } \\
\text { Can it be maintained easily? } \\
\text { Will it have a reduced effect or no harm to the } \\
\text { environment? } \\
\text { Does it reduce the effect of rainfall variability? } \\
\text { Can it enhance soil fertility? } \\
\text { Does it require much land for its } \\
\text { implementation? } \\
\text { Does it enhance crop productivity? }\end{array}$ \\
\hline Affordability & $\begin{array}{l}\text { It should be less limited by financial } \\
\text { constraints, labor and is easily } \\
\text { purchased }\end{array}$ & $\begin{array}{l}\text { Costs } \\
\text { Labor } \\
\text { Availability/easy to } \\
\text { implement }\end{array}$ & $\begin{array}{l}\text { Can it be implemented with a minimum cost? } \\
\text { Is there a cheap labor available for its } \\
\text { implementation? } \\
\text { Are there cheap materials available for its } \\
\text { implementation? }\end{array}$ \\
\hline Effectiveness & $\begin{array}{l}\text { It should be effective in reducing the } \\
\text { risk of rainfall variability (prolongs soil } \\
\text { moisture) and preserving soil nutrients }\end{array}$ & $\begin{array}{l}\text { Rainfall variability } \\
\text { Soil fertility } \\
\text { Productivity }\end{array}$ & $\begin{array}{l}\text { Does it prolong crop growth under rainfall } \\
\text { variability? } \\
\text { Does it conserve soil fertility? } \\
\text { Can it increase crop yield? }\end{array}$ \\
\hline
\end{tabular}

Once the four UPS with the highest overall average scores according to the criteria in Table 2 were selected, we searched for literature that described the biophysical models able to simulate them. The main criterion for model selection was that the reported models must have been used to adequately simulate the selected UPS. The models that were the most robust in simulating these UPS were further described and analyzed. Depending on the number of the UPS simulated by the biophysical models, we ranked the models from those that simulated all the four selected UPS to those which simulated at least one UPS. We described three of the most frequently used models pertaining to the four selected crop UPS. We used the FAO database (FAOSTAT) (http:/ / www.fao.org/faostat/en/\#data, accessed on 7 July 2017) to extract information on cereals' global harvested area and production. We then computed the relationship between the model coverage of the four UPS by counting the number of papers from our collection under each cereal and the global harvested area of the cereals to determine whether there was any association. In addition, we analyzed the relationship between the global harvested area of different cereals and the usage of the four UPS.

\section{Results}

\subsection{Roles of Crop Upgrading Strategies for Cereal Production}

We identified 13 UPS that are useful for cereal crop production (Table 3). 
Table 3. Reported upgrading strategies used for enhancing and securing cereal crop production.

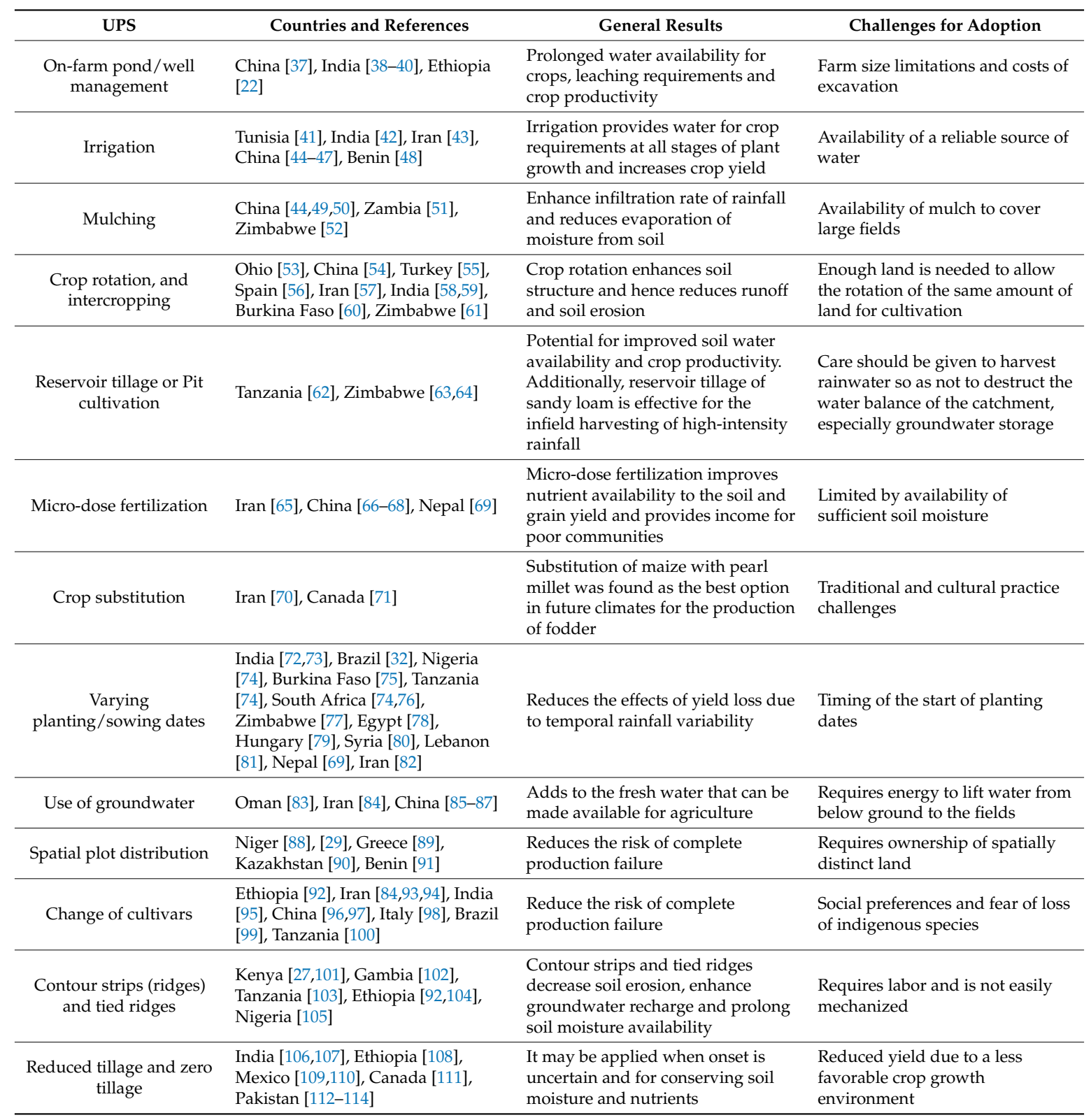

Determining the balance between the strengths and limitations of the UPS is important because these will respectively encourage and discourage farmers during the adoption stages. For instance, in the study on the suitability of on-farm ponds (irrigation), Roost et al. [37] had to analyze soil characteristics in order to understand water dynamics, of which deep percolation was a concern. This implied that even if on-farm ponds are suitable for improving yields, they may work better when soils have a robust ability to retain the stored water. In addition, land availability that can be reserved for ponds within farmers' fields will be a challenge as most poor farmers' landholdings in semi-arid areas have small plot sizes [3]. Thus, sustainability of these practices becomes a challenge since it largely depends on the type of soil. Ponds primary purpose is to supplement a soil moisture deficit through irrigation. Other operational costs such as pumping or intensive labor for water lifting may be needed. Under high rainfall variability water storage for supplemental irrigation is important; the main challenge remains to be affordability and possibility.

Similar concerns arise when we examine the use of groundwater as an alternative source of water for supplemental irrigation [84]. This UPS, despite being important and effective, also faces challenges 
of affordability and possibility as it requires an initial investment for boreholes or a large amount of labor for hand dug wells. Additionally, during irrigation, the operational costs of lifting water via pumping are untenable for most poor farmers. Raising water for irrigation by hand is unattractive due to drudgery work involved. In general, this makes the UPS difficult to implement and labor intensive, and it may also face the challenge of availability of groundwater, hence jeopardizing its adoption possibilities.

Mulching helps to prolong soil moisture by protecting it from excessive evaporation [115], and in that regard is reported as an important strategy by many authors (Table 3). It is socially acceptable, sustainable, environmentally friendly, not constrained by land availability, and helps improving microbial activities in the soil, and productivity. Mulch also is well suited with zero tillage. However, when rainfall is minimal mulch may obstruct rainfall from falling directly on the soil. Under high rainfall variability, mulch works better when combined with a field scattering strategy and it may work with irrigation to improve water use efficiency [49]. The main challenge is mulch availability, and the labor involved in laying down the mulch. Some authors did not find significant advantage for yields when mulch was used [51], and farmers are reluctant to practice mulching [52]. Other UPS such as crop rotation, crop substitution, reservoir/pit tillage, and irrigation using surface water, all have their strengths and weaknesses (Table 3). In our analysis, we found four UPS to be the most suitable for boosting cereal production in semi-arid areas.

In Table 4, the experts' scores for each constraint and criterion related to individual UPS are presented. The results indicate the amplitude of scores but also show that this procedure can identify the most suitable UPS for the target region. For example, irrigation is among the most important and effective UPS to improve crop performance; however, considering the context in which this assessment is done, it is very costly and requires extensive knowledge, thus, scoring very low in affordability and possibility. When considering the four UPS with higher overall scores (Figure 1), the strategies were shift planting/sowing dates, contour strips and tied ridges, spatial plot distribution and micro-fertilization. 
Table 4. Experts' scores for each constraint and criterion related to individual UPS.

\begin{tabular}{|c|c|c|c|c|c|c|c|c|c|c|c|c|c|c|}
\hline 莺 & 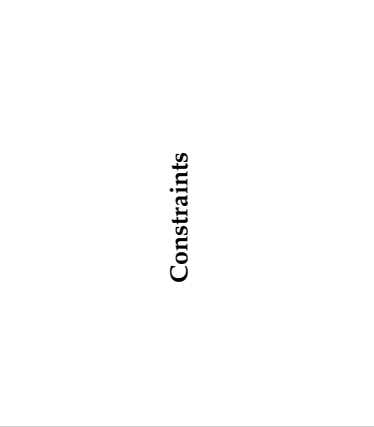 & 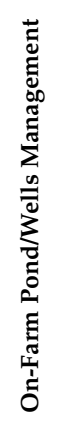 & 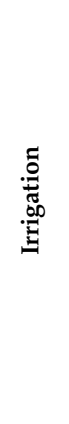 & 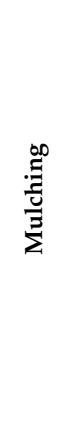 & 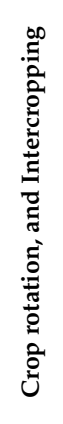 & 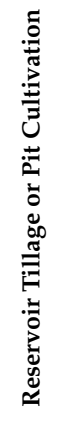 & 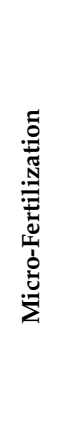 & 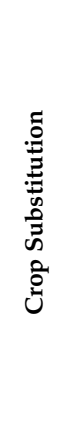 & 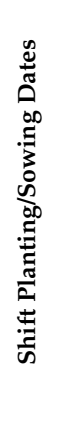 & 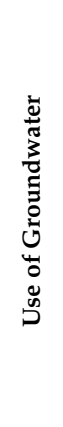 & 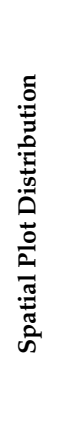 & 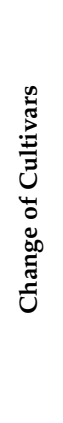 & 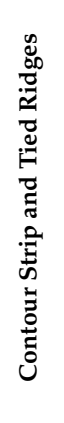 & 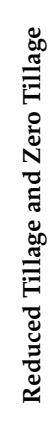 \\
\hline \multirow{9}{*}{ Importance } & Social acceptance & 1 & 3 & 3 & 2 & 3 & 3 & 2 & 3 & 1 & 3 & 2 & 3 & 2 \\
\hline & Labor & 2 & 1 & 2 & 2 & 1 & 3 & 3 & 3 & 1 & 3 & 3 & 2 & 2 \\
\hline & Sustainability & 2 & 2 & 3 & 3 & 2 & 2 & 1 & 3 & 1 & 3 & 2 & 3 & 3 \\
\hline & Environment & 2 & 2 & 3 & 3 & 3 & 2 & 3 & 3 & 1 & 3 & 2 & 3 & 3 \\
\hline & Rainfall variability & 2 & 2 & 1 & 2 & 3 & 2 & 2 & 3 & 3 & 3 & 2 & 3 & 2 \\
\hline & Soil fertility & 2 & 2 & 2 & 2 & 2 & 3 & 1 & 2 & 1 & 2 & 1 & 2 & 2 \\
\hline & Land availability & 1 & 1 & 2 & 2 & 2 & 3 & 3 & 3 & 1 & 1 & 3 & 3 & 3 \\
\hline & Productivity & 3 & 3 & 2 & 2 & 2 & 3 & 2 & 3 & 3 & 3 & 2 & 3 & 2 \\
\hline & Average & 2.1 & 2.0 & 2.3 & 2.3 & 2.3 & 2.6 & 2.1 & 2.9 & 1.5 & 2.6 & 2.1 & 2.8 & 2.4 \\
\hline \multirow{4}{*}{ Affordability } & Costs & 1 & 1 & 2 & 2 & 2 & 2 & 2 & 3 & 1 & 3 & 2 & 2 & 2 \\
\hline & Labor & 1 & 1 & 1 & 2 & 2 & 2 & 3 & 2 & 1 & 1 & 2 & 2 & 2 \\
\hline & Availability/easy to implement & 1 & 1 & 1 & 2 & 2 & 2 & 1 & 3 & 2 & 3 & 2 & 3 & 3 \\
\hline & Average & 1.0 & 1.0 & 1.3 & 2.0 & 2.0 & 2.0 & 2.0 & 2.7 & 1.3 & 2.3 & 2.0 & 2.3 & 2.3 \\
\hline \multirow{5}{*}{ Possibility } & Easy to implement & 1 & 1 & 1 & 2 & 2 & 2 & 1 & 3 & 2 & 3 & 2 & 3 & 3 \\
\hline & Social acceptance & 2 & 3 & 1 & 2 & 2 & 3 & 1 & 3 & 1 & 3 & 1 & 3 & 2 \\
\hline & Labor & 1 & 1 & 1 & 2 & 2 & 2 & 3 & 2 & 1 & 1 & 2 & 2 & 2 \\
\hline & Land availability & 1 & 1 & 3 & 2 & 3 & 3 & 3 & 2 & 2 & 2 & 3 & 3 & 3 \\
\hline & Average & 1.3 & 1.5 & 1.5 & 2.0 & 2.3 & 2.5 & 2.0 & 2.5 & 1.5 & 2.3 & 2.0 & 2.8 & 2.5 \\
\hline \multirow{4}{*}{ Effectiveness } & Rainfall variability & 2 & 3 & 1 & 2 & 3 & 2 & 2 & 3 & 3 & 3 & 2 & 3 & 2 \\
\hline & Soil fertility & 2 & 2 & 2 & 2 & 2 & 3 & 1 & 2 & 1 & 2 & 1 & 2 & 2 \\
\hline & Productivity & 3 & 3 & 2 & 2 & 2 & 3 & 2 & 3 & 3 & 3 & 2 & 3 & 2 \\
\hline & Average & 2.3 & 2.7 & 1.7 & 2.0 & 2.3 & 2.7 & 1.7 & 2.7 & 2.3 & 2.7 & 1.7 & 2.7 & 2.0 \\
\hline
\end{tabular}






Figure 1. Ranking of UPS using total average scores from Table 4.

\subsection{Modelling Cereal Crops UPS for Enhancing Production}

Many models have successfully simulated the four selected crop UPS and have suggested methods to tackle the production challenges of cereal crops in semi-arid areas. Examples of these models include DSSAT, APSIM, AquaCrop, HYDRUS-2D, EPICSEAR, MSM and others (Table 5).

Table 5. Different models reported for simulating UPS in semi-arid areas.

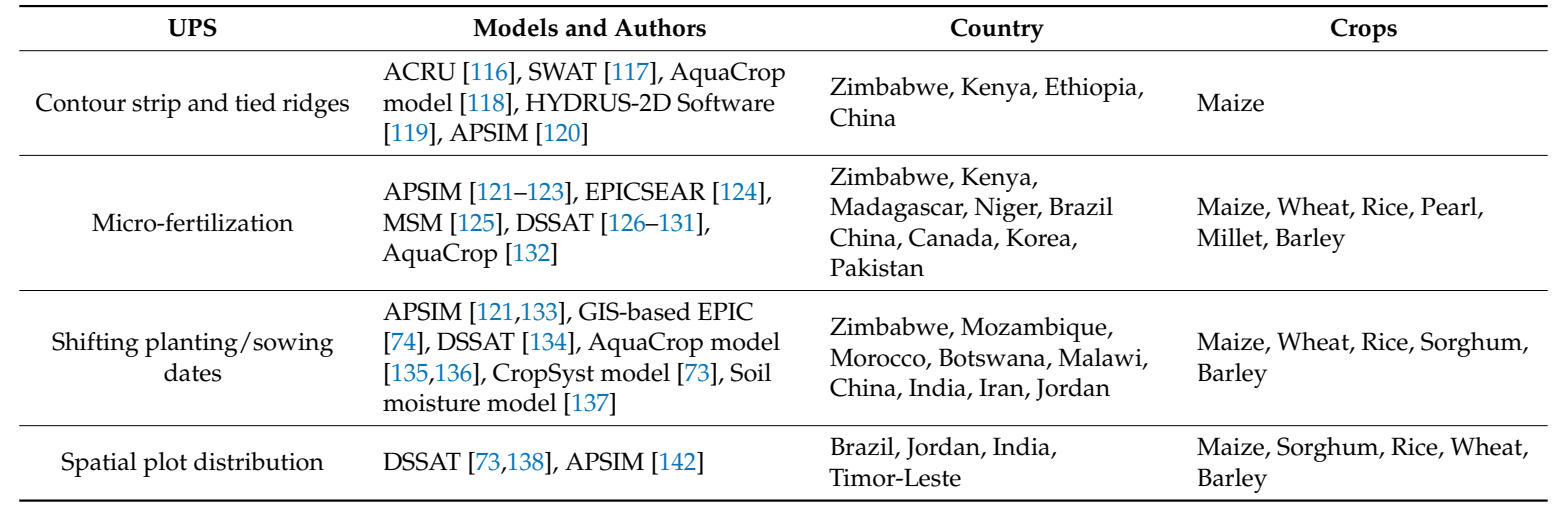

Definitions of the model acronyms: ACRU-Agricultural Research Unit simulation model; SWAT-Soil and Water Assessment Tool; AquaCrop—crop-water productivity model; HYDRUS-2D—a software package for simulating water, heat, and solute movement in two- and three-dimensional variably saturated media; APSIM-Agricultural Production Systems Simulator model; MSM-An integrated water and N Maize Simulation Model; DSSAT—Decision Support System for Agrotechnology Transfer; EPIC—Environmental Policy Integrated Climate; EPICSEAR - newly developed version derived from the Erosion Productivity Impact Calculator model for simulating crop production and nutrient uptake on highly weathered, acidic soils; CropSyst-Cropping Systems Simulation Model; Soil moisture model—a continuous soil water balance model for the simulation of soil moisture temporal evolution.

In general, the simulations of UPS for semi-arid climates are reported by only a few papers compared to the multitude of papers available on modelling/simulation. We found that 30 out of the 187 papers contained in this review specifically covered the modelling of at least one of the four selected 
UPS in semi-arid areas. One strong reason for such a shortage is the limitation in the availability of, and access to, quality data $[100,143,144]$. Maize was covered by $51 \%$ of the papers reviewed. The other cereal crops that were covered were wheat $(23 \%)$, rice $(10 \%)$, barley $(8 \%)$, sorghum $(5 \%)$ and pearl millet ( $3 \%$ ), (Figure 2). We found a strong positive correlation (r) between the global harvested area and the frequency of crop coverage by the models in the papers that simulated the four crop UPS in semi-arid regions (Figure 2). Thus, the cereals with large global harvest areas not only possess a good chance to be cultivated with UPS but also attract more modelling studies to improve their production. This is evident because the three major cereal crops (wheat, rice, and maize), which occupy more than $80 \%$ of the global area of harvest for cereals, show a high frequency of usage of models and UPS (Figure 2) compared to millet sorghum and barley. We also found a relationship between the productivity of global cereals (Table 6) and their frequency of model coverage for the UPS in the reviewed papers, which may best be represented by a quadratic model (Figure 3).

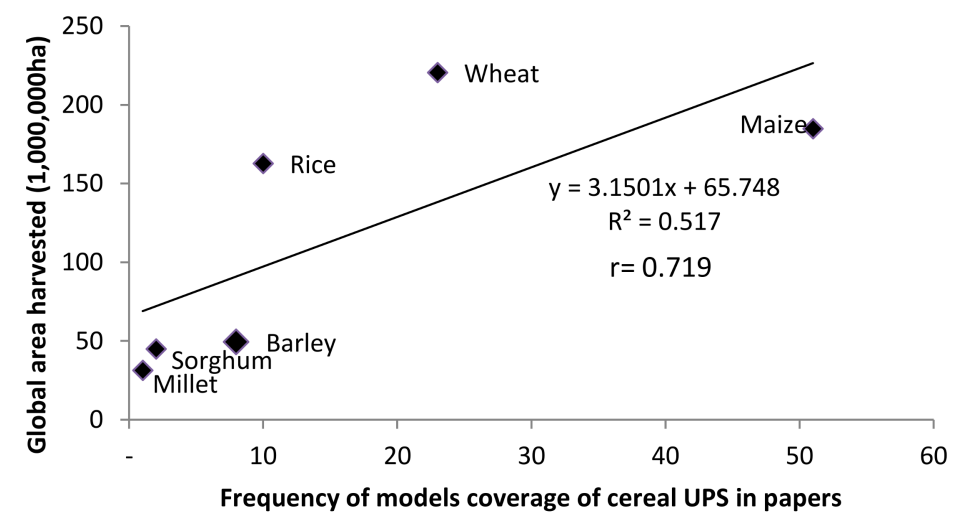

Figure 2. Relationship between global harvested area and frequency of the model coverage of cereal UPS in papers (number of papers), data from FAOSTAT, 2014 accessed on 7 July 2017.

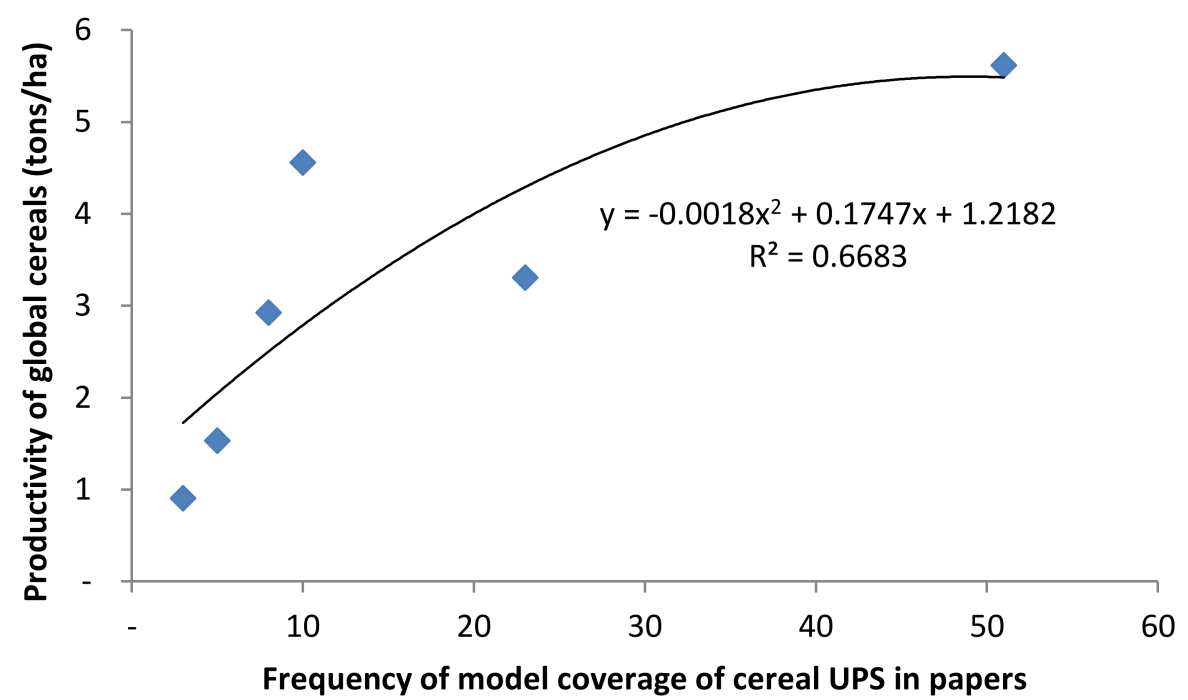

Figure 3. Relationship between the productivity of global cereals and frequency of the model coverage of cereal UPS in papers (number of papers), data from FAOSTAT, 2014 accessed on 7 July 2017. 
Table 6. Global productivity area of cereals (FAOSTAT, 2014 accessed on 7 July 2017).

\begin{tabular}{cc}
\hline Crop & Production tons/ha \\
\hline Barley & 2.92 \\
Maize & 5.62 \\
Millet & 0.90 \\
Rice & 4.56 \\
Sorghum & 1.53 \\
Wheat & 3.31 \\
\hline
\end{tabular}

Crops such as pearl millet and sorghum, which are among the major staple food crops in semi-arid areas, especially in Africa, have gained less modelling attention. This lack of attention could be due to the disadvantage related to global harvest area, as explained by the relationship in Figure 2. This disadvantage is also due to the population that consumes these crops which is small when compared to other cereals. The relationship can be associated with the analysis of White [145]. However, these crops can be of major importance locally as they represent large potential for reducing food insecurity and poverty in semi-arid areas.

From our review, we selected three models to describe and discuss; these are DSSAT, APSIM and AquaCrop. These models cover the four UPS adequately. In summary, in this paper's framework, the DSSAT model dominated the studies, followed by APSIM and AquaCrop. The reason for the dominance of these models can be understood further through their descriptions and discussion, which is also presented in this paper.

\section{Discussion}

The choice of UPS depends on the involvement of stakeholders and their knowledge of labor limitations, financial constraints, restrictive governmental policies, environmental and climatic conditions, social and cultural conditions and related food security risks [20]. Thus, UPS are important to sustainable crop production and food security. In our review, all 13 UPS were found to be suitable for improving production; however, they all had constraints in their adoption. In Tables 2 and 4 we have identified the constraints, assigned a score as supported by the literature and ranked the UPS according to the average scores of the constraints. The scores of the constraints were given by experts as a result of the understanding found in the literature describing the ability of the UPS to overcome these constraints. We have picked the four highest ranked UPS and described them below.

\subsection{Contour Ridges and Tied Ridges}

"A ridge is a long, narrow, elevated strip of land or any raised strip or band. A ridge is called a contour ridge when it is created along the upslope furrow to accommodate runoff from a catchment strip between the ridges that are 15 to $20 \mathrm{~cm}$ high" [146]. "These ridges may be 1.5 to $10.0 \mathrm{~m}$ apart depending on the microcatchment system, as the catchment is a function of the distance between ridges. The precise distance should be calculated according to the expected rainfall and the soil texture of the region" [146]. When a ridge is crossed by the ridge of another perpendicular earthen band, it is called a tied ridge (Figure 4). "Small earthen ties are made within the furrows at 4 to $5 \mathrm{~m}$ intervals to prevent the lateral flow of water. The main objective of a tied ridge system is to collect local water runoff and store it within the soil profile in the vicinity of the plant roots" [146].

Tied ridges prolong the retention of soil moisture and enhance nutrient uptake by crops [101,104,147]. Tied ridges provide a better crop growth environment $[102,148,149]$ in areas where the temporal rainfall variability is a challenge. Evidence of higher cereal yields and increased rain water use efficiency $[27,101]$, and even better income [92,104], have been reported. Tied ridges can be improved to be more effective, for instance by combining tied ridges with microdosage techniques [147]. This UPS is found to be the most useful in reducing the acuteness of temporal rainfall variability. 


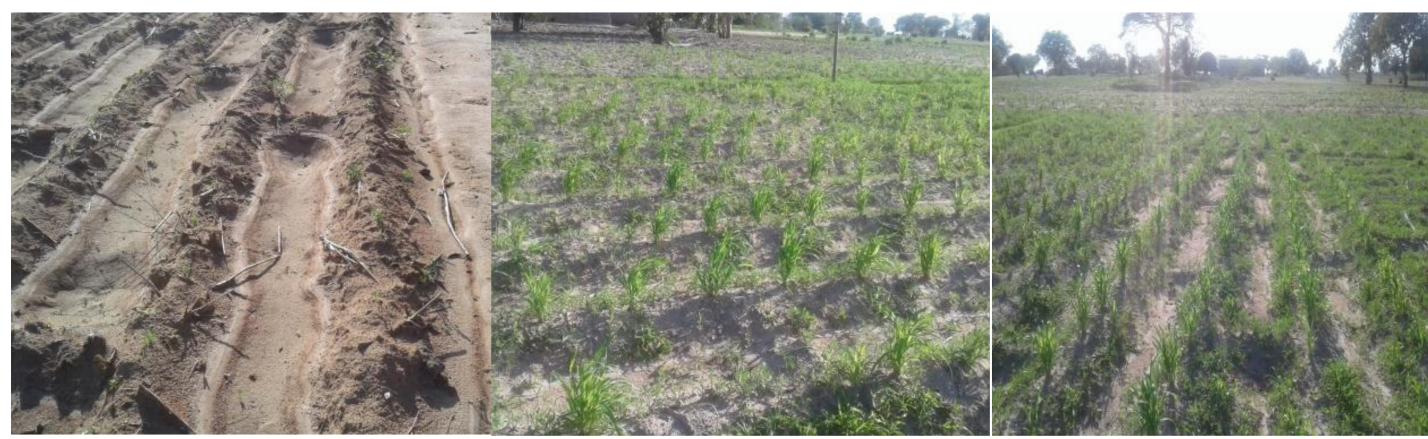

Figure 4. Examples of tied ridges planted with pearl millet in Idifu-Dodoma, Tanzania.

Araya and Stroosnijder [104] report that tied ridging and mulching can increase soil water availability in the root zone by more than $13 \%$ and crop grain yield (barley) by at least $44 \%$ during below average rainfall years. Other evidence shows that tied ridges are beneficial in drought-prone areas. Arid and semi-arid areas can benefit from enhanced production, up to five times greater, of sorghum yields grown in loamy soils [103].

Care should be taken when farming using tied ridges, and it is advised to carefully open the ridges when excess water is expected to cause waterlogging [104]. Thus, when rainfall is well distributed during the cropping season, tied ridging is not a necessary tillage alternative for cereals such as maize on flat land. However, when tied ridges are used in areas with modest slopes, they markedly increase soil water reserves at 0.15 to $0.60 \mathrm{~m}$ depths after maize harvest [102]. This strategy is limited by the difficulties related to mechanization [150] and excess rainfall. The limitations necessitate "an assessment of the major agro-meteorological challenges, existing tillage, hoeing and associated land management practices" [150].

\subsection{Micro-Fertilization}

After water availability, soil nutritional status is the greatest constraint to food production across the arid and semi-arid SSA countries [105,151,152]. When soil moisture is adequate for plant growth, the crop will reach its maximum growth potential if nutrient supply is adequate. Several authors have reported a challenge of poor soil fertility that farmers in semi-arid areas are facing [153-155]. The problem is acute for poor farmers in semi-arid Sub-Saharan Africa countries [151,156,157]. The precision-farming technique referred to as "microdosing" has been developed by experts [158-160]. It "involves the application of small quantities of fertilizer with the seed at the time of planting or as top dressing three to four weeks after emergence" [161]. This method enhances the efficiency of fertilizer use when compared to the broadcasting application method. Micro-fertilization helps poor farmers increase the returns on small initial investments [160,162].

In agreement with Bielders and Gerard [162], farmers have to develop the capacity to apply recommended amounts of fertilizer over time. The best option could be the application of manure or organic fertilizers. However, manure availability can be a challenge for farmers who are not livestock keepers. In such conditions, microdose fertilization remains an important option to these farmers. So far, microdosing has been introduced in Zimbabwe, Mozambique, and South Africa, which are in the southern part of the African continent $[151,157]$. Farmers apply fertilizer in small quantities (micro-fertilization) to cover large areas of their farms, and this method has helped them increase crop yields [163]. The results from Niger and Mali show a yearly average of $20 \mathrm{~kg} \mathrm{P}_{2} \mathrm{O}_{5} \mathrm{ha}^{-1}$ and $30 \mathrm{~kg} \mathrm{~N} \mathrm{ha}^{-1}$ increased stover yields by 400 to $1500 \mathrm{~kg} \mathrm{ha}^{-1}$, and the stover yield was not further increased with higher application rates of $40 \mathrm{~kg} \mathrm{P}_{2} \mathrm{O}_{5}$ ha $^{-1}$ and $60 \mathrm{~kg} \mathrm{~N} \mathrm{ha}^{-1}$ [164]. Similar reports of millet yield success have been reported in Niger [162]. Other promising results from initial on-farm trials in Zimbabwe show increases in yield by $30-100 \%$ when microdoses, as little as $10 \mathrm{kgN} \mathrm{ha}^{-1}$ [151] were applied. 
Thus, micro-fertilization UPS are recommended in low-yielding plots, as microdosing in plots with minimum yield bears a non-negligible financial risk [151]. Twomlow et al. [151] reported that micro-fertilization was an effective strategy to counteract the disadvantages of late sowing, and it better suited as a means of famine mitigation [151]. They provided yield data that smallholder farmers could increase their yields by $30-100 \%$ through application of micro-fertilization as little as $10 \mathrm{~kg}$ Nitrogen ha ${ }^{-1}$ [151]. However, these experiences from West Africa have shown that the adoption of micro-fertilization technology requires supportive and complementary institutional innovation [151]. The major constraints to the adoption of this strategy are the initial access to fertilizer, access to credit, insufficient flows of information and training to farmers, and inappropriate policies [151]. Of much interest is what additional benefits can be obtained by combining microdose fertilization with other UPS, such as varying planting dates, tied ridges and field scattering.

\subsection{Varying Sowing/Planting Dates as a Measure to Counteract Rainfall Uncertainties}

Varying planting dates increases the efficiency of the use of available water or rainfall and it has the potential to reduce the risk of temporal rainfall variability [29]. Under current climate change and variability, the onset of seasonal rainfall is uncertain for most years [76,165-167]. Therefore, farmers cannot rely on the planting dates they previously used. To reduce the risk of total production failure, farmers are advised to vary planting dates to capture the best planting date for the season. This method guarantees the probability of at least one planting date secures a harvest. In this case, the timing of the start of planting dates is crucial and very challenging [74].

In addition, a challenge related to the affordability remains, as poor farmers have a limited capacity to purchase enough seeds to cover several planting dates. A study in Southern Africa established optimum planting dates for six locations. These dates were from the 5 to 27 December, 26 December to 7 January, and 4 to 7 December for Malawi, Mozambique, and Zimbabwe, respectively [76]. Sacks et al. [168] discovered that maize planting dates might vary more widely in tropical regions. The findings reflected that sowing time can be optimized for stable rainfed maize yields, but the effect of sowing dates on rainfed maize yield is modified by both soil depth and soil fertility.

In general, varying sowing/planting dates increases the chance of crop production under high temporal rainfall variability; for some cereal crops, this strategy has significantly influenced seed germination, plant height, tillering, total biomass, and overall grain yield and water productivity under rainfed conditions. Such cereals include wheat $[168,169]$, rice $[170,171]$, maize $[172,173]$ and sorghum [174-176]. The weakness of the method is related to the difficulties in controlling the harvest loss for all dates combined. Thus, this strategy provides an opportunity for farmers to have a wide range of planting date options that can help them secure a possible optimum harvest for the season. The timing of planting should be adjusted based on the forecast of the onset of seasonal rainfall to harness the maximum potential of available seasonal rainfall.

\subsection{Spatial Plot Distribution as a Measure to Combat Spatial Rainfall Variability}

Rainfall can vary over a spatial distance as small as $800 \mathrm{~m}$ [29]. Efforts to protect crop yields from the impacts of climate change should, therefore, consider spatial rainfall variations [177]. Spatial plot distribution (cultivating fields at different locations within a few kilometers) reduces the risk of complete production failure when there is less rainfall and high spatial variability in the area; however, fields cannot avoid production losses altogether [29,30]. The spatial plot distribution strategy has been successfully used in Niger [29] and Nigeria [30]. Spatial plot distribution is limited by land and financial resources of farmers to be able to farm fields in different locations. The strategy is useful in areas that are not constrained by land resources and have low rainfall with high spatial variability $[29,30]$. 


\subsection{Roles of Models for Cereal UPS}

The models are good at exploring different questions that arise from the limitations of UPS at the field level and extrapolating the results to a large scale that allows for more informed decision making [178]. Modelling and simulation studies help in making more sensible decisions for the current climatic status and the future production of cereals. They provide an alert for the measures to take in case food security is at risk. The models should subsequently be improved as they have several limitations, as described below.

\subsubsection{Description of DSSAT-Models}

The "decision support system for agrotechnology transfer" (DSSAT) encompasses 16 different crop models for different evaluation purposes [179]. The models in DSSAT integrate the effects of soil, crop phenotype, management options and weather. A DSSAT model has been adopted in a wide range of countries and continents (Table 5), which indicates its strength in accommodating a wide range of climatic and agricultural conditions. For instance, one simulation study found clear signs of decline in the future production of maize and rice in India [73]. Additionally, they determined that shifting planting dates would have a positive impact on production. Rezaei et al. [70] used the DSSAT model and found that maize crops could be substituted by pearl millet to counter yield reduction in the future, while other studies have suggested that a change of cultivar would be an option to sustain food production in the future [32,180].

In this survey, we found that the models have satisfactorily explained farmers' attitudes to planting/sowing time, microdosage under nutrient management, and scattered field or spatial field dispersion. In most of the papers, data used for calibration were daily weather records, measured physical, chemical, and morphological characteristics of the soils as model inputs, and crop genetic coefficients that are specific to each cultivar of interest. In a study by Jagtap and Abamu [127], DSSAT model used farmers" planting dates to simulate maize growth and found that "early planting together with manure from cattle allowed to graze on crop residues increased yield response to fertilizer $\mathrm{N}^{\prime \prime}$ [127]. The results also showed that changing the planting date by 30 days (more or less) had minimal effect on obtainable maize grain yields in production systems characterized by high $\mathrm{N}$ inputs (120-150 kg/ha) [127].

DSSAT offers nutrient management functions, where fertilizer application can be varied from optimum to minimum applications (micro-fertilization). Nutrient management has been simulated extensively and reported by many authors. For example, Gerardeaux et al. [129] used the DSSAT 4.5 cropping system model (DSSAT-CSM) to explain the impact of various climate changes on rice productivity in Madagascar using two tillage strategies and two fertilization rates: low and high nitrogen. They used a locally cultivated rice cultivar to calibrate and validate the model, with a 6-year experimental data set. Nitrogen was found to be a major constraint while zero tillage demonstrated no advantage in addressing impacts of climate change. Another study by Jeong et al. [130] using DSSAT found that adjusting the split $\mathrm{N}$ fertilizer application rate was enough to attain a satisfactory yield of rice, providing an additional 10-20 kg/ha. Other studies also done on wheat [126], pearl millet [131] and maize $[32,125]$ demonstrated the potential of using DSSAT in simulating fertilizer microdosage.

DSSAT has also been reported to simulate field scattering as an UPS for improving cereal yields in semi-arid areas. In a study by Jalota and Vashisht [73], they found that "in the future, the magnitude of climate change and variability would vary with agro-climatic zone" as well as the yields of maize and rice [73]. A simulation of wheat at different locations using a DSSAT model [140] also recorded different yields, which were a result of different agro-climatic zones within India. Hurtado et al. [138] also reported that the DSSAT was able to simulate corn yields related to field spatial variability. The authors used data of "maximum and minimum temperatures, rainfall and solar radiation; soil data in the 0-27, $27-45,45-68,68-80$ and 80-100 cm layers to each experimental plot, management information of corn crop and genetic parameters of the corn hybrid" [138]. The authors reported that the DSSAT was able to simulate yields as related to the spatial variables of the soil attribute base saturation. 
Although DSSAT models are reported to adequately simulate planting dates, micro-fertilization and spatial plot distribution UPS, we found no evidence that DSSAT models were used to simulate tied ridges strategies. This is a gap that crop modelers may be required to fill as this UPS is among the four prioritized UPS found to be effective in reducing the adverse effects of rainfall variability and in conserving soil fertility and moisture during crop growth in semi-arid areas. Another summary of the strengths and weaknesses of DSSAT models is presented by Brilli et al. [181]. The limitations reported include overestimation or underestimation of soil organic carbon and soil nitrogen.

\subsubsection{Description of APSIM Model}

"The Agricultural Production Systems Simulator (APSIM)" [182]simulates several systems and addresses the interactions among plants, animals, soil, climate, and management. The model allows for the analysis of a whole-farm system, including crop and pasture sequences and rotations, and livestock [182]. Maize was found to be a dominant crop simulated by the APSIM model followed by wheat and sorghum. For example, Ngugi et al. [120] adopted the APSIM model for a scenario analysis of the effect of tied ridges on maize yield in two study sites in Kenya and found different responses to tied ridges and fertilizer application. In general, when combined, tied ridges and fertilizer application boosted the maize yield significantly [120]. This provides evidence for the concept of combining different UPS to counteract the effect of rainfall variability and poor soil fertility. In this study, the combined UPS increased yields of maize grain between 507-3370 kg/ha [120].

In Zimbabwe, the APSIM model was used to explore the "risk associated with $\mathrm{N}$ fertilizer use by smallholder farmers and management strategies to minimize that risk" [121]. They used long term data from Nitrogen fertilizer maize trials for calibration and validation of the model before using it in their exploration. In their results, they found moderate fertilizer application rates and early sowing will give economic benefits to farmers [121,122]. Kisaka et al. [122] found similar results in Kenya and recommended that "for subsistence farming, low-cost recommendations are geared towards some 'guaranteed' yield stability each cropping season" [122]. Ahmed et al. [123] also calibrated and validated the APSIM model and used it to predict nitrogen use efficiency of wheat under rain-fed conditions for the Pothwar region of Pakistan. The simulation revealed the potential of the APSIM model to provide fertilizer recommendation rates that may achieve agricultural production and economic benefits, a finding that is in agreement with [142].

In the study by Ngugi et al. [120], the authors reported the potential of the APSIM model to inform the planting dates UPS. They found that timing of planting was key in improving yields. The results are in agreement with Heng et al. [133] who reported that "early sowing is important for achieving high yields by avoiding terminal water deficit" [133]. The algorithm for simulating planting dates in the model provides opportunities to determine optimum planting dates, which can help farmers to avoid total crop failure. The model, in addition, could "simulate maize yields at four locations with 8 years of reliable weather records" [142], which highlights the potential of the model in determining the effect of spatial plot distribution UPS. Under high spatial rainfall variability, the model can help in predetermining the potential positions of fields where farmers can expect to obtain optimum yields.

Some of the weaknesses of the model have been summarized by [181], which include underestimation of soil nitrogen and soil organic component, overestimation of annual leaching, and underestimation/overestimation of $\mathrm{N}_{2} \mathrm{O}$ emissions. In this regard, the APSIM model still requires periodic improvements so that it can be used with more certainty. In addition, [181] provides a detailed summary and review of the strengths and weaknesses of the APSIM model.

\subsubsection{Description of the AquaCrop Model}

"The AquaCrop model simulates major herbaceous crops as a function of water consumption under rainfed, supplemental, deficit, and full irrigation conditions" [183]. It also simulates evapotranspiration as separately soil evaporation and crop transpiration. The model also simulates the biomass accumulated each day using crop specific parameters that are normalized for reference 
evapotranspiration [183-185], which makes the model useful to in different climates [132,186,187]. The model has been successfully used to simulate different cereal UPS in semi-arid areas. We found six papers that discussed planting dates for maize [77,184], barley [136,186], winter wheat [135], and varying nitrogen levels (microdose fertilization) for maize [132]. We found the model to have the potential for extrapolating successful cereal UPS in arid and semi-arid areas. Expansion of the usage of the model for simulating tied ridges and modifying the model to accommodate spatial field dynamics will be of importance for its robust usage.

Most of the weaknesses of the AquaCrop model are mentioned on the FAO website for land and water (http:/ / www.fao.org/aquacrop/overview/limitations/en/). Our overview finds that the weaknesses resemble the limitations of DSSAT and APSIM. These limitations include the following: (i) AquaCrop simulates a single growth cycle only; (ii) the model predicts crop yields at a single point in its simulations [183] and assumes that the field is uniform without spatial differences in crop development, transpiration, soil characteristics or management [183]; and (iii) the AquaCrop model considers only incoming vertical (irrigation capillary and rainfall rise) and outgoing (transpiration, deep percolation and evaporation) water fluxes in its simulations [183].

\section{Conclusions}

Four UPS were identified as the most promising to improve rainfed cereal production for poor farmers in semi-arid areas. These UPS are tied ridges, microdose fertilization, varying sowing/planting dates and field scattering. These strategies are suitable for reducing the risks of cereal production failure under low rainfall, high spatiotemporal variability, and poor soil fertility conditions.

Among the different biophysical models, three of them-namely, DSSAT, APSIM and AquaCrop-have more frequently studied the four selected UPS. We found that both the strengths and the weaknesses of these models were comparable. In general, the models have performance weaknesses when temporal and spatial variations in soil moisture, soil temperature and aeration are considered. In addition, they do not include algorithms for each UPS or for soil organic content and they consider only vertical water fluxes. The frequency of the use of models is an important proxy for their robustness. This assessment also identified the main points necessary to improve the selected UPS's. Despite their limitations, we encourage researchers and decision makers to use these models since they have been instrumental in research and decision-making.

Acknowledgments: The research conducted in this study has received funding from the German Federal Ministry of Agriculture and Food (BMEL) in the frame of PhD program by the Federal Office of Agriculture and Food (BLE). The preparation and publication of this article is funded by Leibniz Center for Agricultural Landscape Research (ZALF).

Author Contributions: Festo Richard Silungwe conceived, designed, and drafted the paper, Frieder Graef and Marcos Alberto Lana revised the design of the paper, contributed to its writing, and provided additional literature, Sonoko Dorothea Bellingrath-Kimura revised the paper and contributed substantially to its writing, Frederick Cassian Kahimba and Siza Donald Tumbo contributed to revision and supplementing text.

Conflicts of Interest: The authors declare no conflict of interest.

\section{References}

1. World Food Summit. World Food Summit in FAO, Volume 1; World Food Summit: Rome, Italy, 1996; pp. 23-30.

2. Bawadi, H.A.; Tayyem, R.F.; Dwairy, A.N.; Al-Akour, N. Prevalence of Food Insecurity among Women in Northern Jordan. J. Health Popul. Nutr. 2012, 30, 49-55. [CrossRef] [PubMed]

3. Food and Agriculture Organization. Comprehensive Food Security \& Vulnerability Analysis (CFSVA), Tanzania; FAO: Rome, Italy, 2013.

4. Brown, M.E.; Hintermann, B.; Higgins, N. Markets, Climate Change, and Food Security in West Africa. Environ. Sci. Technol. 2009, 43, 8016-8020. [CrossRef] [PubMed]

5. Haug, R.; Hella, J. The art of balancing food security: Securing availability and affordability of food in Tanzania. Food Secur. 2013, 5, 415-426. [CrossRef] 
6. Webber, H.; Gaiser, T.; Ewert, F. What role can crop models play in supporting climate change adaptation decisions to enhance food security in Sub-Saharan Africa? Agric. Syst. 2014, 127, 161-177. [CrossRef]

7. Hussein, K. Food security: Rights, livelihoods and the World Food Summit-Five years later. Soc. Policy Adm. 2002, 36, 626-647. [CrossRef]

8. Paul, K.H.; Muti, M.; Khalfan, S.S.; Humphrey, J.H.; Caffarella, R.; Stoltzfus, R.J. Beyond food insecurity: How context can improve complementary feeding interventions. Food Nutr. Bull. 2011, 32, 244-253. [CrossRef] [PubMed]

9. McCoy, S.I.; Ralph, L.J.; Njau, P.F.; Msolla, M.M.; Padian, N.S. Food Insecurity, Socioeconomic Status, and HIV-Related Risk Behavior among Women in Farming Households in Tanzania. Aids Behav. 2014, 18, 1224-1236. [CrossRef] [PubMed]

10. Asfaw, S.; Shiferaw, B.; Simtowe, F.; Lipper, L. Impact of modern agricultural technologies on smallholder welfare: Evidence from Tanzania and Ethiopia. Food Policy 2012, 37, 283-295. [CrossRef]

11. Shiferaw, B.; Kassie, M.; Jaleta, M.; Yirga, C. Adoption of improved wheat varieties and impacts on household food security in Ethiopia. Food Policy 2014, 44, 272-284. [CrossRef]

12. Lal, R. Sustainable horticulture and resource management. In Proceedings of the International Symposium on Sustainability through Integrated and Organic Horticulture; Prange, R.K., Bishop, S.D., Eds.; International Society for Horticultural Science: Leuven, Belgium, 2008; pp. 19-43.

13. Bakewell-Stone, P.; Lieblein, G.; Francis, C. Potentials for organic agriculture to sustain livelihoods in Tanzania. Int. J. Agric. Sustain. 2008, 6, 22-36. [CrossRef]

14. Berry, E.M.; Dernini, S.; Burlingame, B.; Meybeck, A.; Conforti, P. Food security and sustainability: Can one exist without the other? Public Health Nutr. 2015, 18, 2293-2302. [CrossRef] [PubMed]

15. FAO. Regional Overview of Food Insecurity: African Food Security Prospects Brighter Than Ever; FAO: Accra, Ghana, 2015.

16. Baro, M.; Deubel, T.F. Persistent hunger: Perspectives on vulnerability, famine, and food security in Sub-Saharan African. In Annual Review of Anthropology; Annual Reviews: Palo Alto, CA, USA, 2006; pp. 521-538.

17. Kassie, B.T.; van Ittersum, M.K.; Hengsdijk, H.; Asseng, S.; Wolf, J.; Rotter, R.P. Climate-induced yield variability and yield gaps of maize (Zea mays L.) in the Central Rift Valley of Ethiopia. Field Crops Res. 2014, 160, 41-53. [CrossRef]

18. Kassie, M.; Jaleta, M.; Shiferaw, B.; Mmbando, F.; Mekuria, M. Adoption of interrelated sustainable agricultural practices in smallholder systems: Evidence from rural Tanzania. Technol. Forecast. Soc. Chang. 2013, 80, 525-540. [CrossRef]

19. Akinyoade, A.; Dietz, T.; Leliveld, A. Agricultural Pockets of Effectiveness in Africa a Comparative Inventory of Nigeria, Kenya, Tanzania and Uganda since 2000. In Digging Deeper: Inside Africa's Agricultural, Food and Nutrition Dynamics; Akinyoade, A., Klaver, W., Soeters, S., Foeken, D., Eds.; Brill: Leiden, The Netherlands, 2014; pp. 55-82.

20. Graef, F.; Schneider, I.; Fasse, A.; Germer, J.U.; Gevorgyan, E.; Haule, F.; Hoffmann, H.; Kahimba, F.C.; Kashaga, L.; Kissoly, L.; et al. Assessment of upgrading strategies to improve regional food systems in Tanzania: Food processing, waste management and bioenergy, and income generation. Outlook Agric. 2015, 44, 179-186. [CrossRef]

21. Martinez-Alvarez, V.; Garcia-Bastida, P.A.; Martin-Gorriz, B.; Soto-Garcia, M. Adaptive strategies of on-farm water management under water supply constraints in south-eastern Spain. Agric. Water Manag. 2014, 136, 59-67. [CrossRef]

22. Dile, Y.T.; Karlberg, L.; Daggupati, P.; Srinivasan, R.; Wiberg, D.; Rockstrom, J. Assessing the implications of water harvesting intensification on upstream-downstream ecosystem services: A case study in the Lake Tana basin. Sci. Total Environ. 2016, 542, 22-35. [CrossRef] [PubMed]

23. Wichelns, D.; Qadir, M. Achieving sustainable irrigation requires effective management of salts, soil salinity, and shallow groundwater. Agric. Water Manag. 2015, 157, 31-38. [CrossRef]

24. Zhang, B.B.; Feng, G.; Kong, X.B.; Lal, R.; Ouyang, Y.; Adeli, A.; Jenkins, J.N. Simulating yield potential by irrigation and yield gap of rainfed soybean using APEX model in a humid region. Agric. Water Manag. 2016, 177, 440-453. [CrossRef]

25. Yan, N.N.; Wu, B.F.; Perry, C.; Zeng, H.W. Assessing potential water savings in agriculture on the Hai Basin plain, China. Agric. Water Manag. 2015, 154, 11-19. [CrossRef] 
26. Guo, K.; Liu, X.J. Infiltration of meltwater from frozen saline water located on the soil can result in reclamation of a coastal saline soil. Irrig. Sci. 2015, 33, 441-452. [CrossRef]

27. Njeru, P.N.M.; Mugwe, J.; Maina, I.; Mucheru-Muna, M.; Mugendi, D.; Lekasi, J.K.; Kimani, S.K.; Miriti, J.; Oeba, V.O.; Esilaba, A.O.; et al. Integrating Farmers and Scientific Methods for Evaluating Climate Change Adaptation Options in Embu County. In Adapting African Agriculture to Climate Change: Transforming Rural Livelihoods; Filho, W.L., Esilaba, A.O., Rao, K.P.C., Sridhar, G., Eds.; Springer: Cham, Switzerland, 2015; pp. 185-197.

28. Hunink, J.E.; Contreras, S.; Soto-Garcia, M.; Martin-Gorriz, B.; Martinez-Alvarez, V.; Baille, A. Estimating groundwater use patterns of perennial and seasonal crops in a Mediterranean irrigation scheme, using remote sensing. Agric. Water Manag. 2015, 162, 47-56. [CrossRef]

29. Graef, F.; Haigis, J. Spatial and temporal rainfall variability in the Sahel and its effects on farmers' management strategies. J. Arid Environ. 2001, 48, 221-231. [CrossRef]

30. Babatolu, J.S.; Akinnubi, R.T. Smallholder Farmers Perception of Climate Change and Variability Impact and Their Adaptation Strategies in the Upper and Lower Niger River Basin Development Authority Areas, Nigeria. J. Petroleum Environ. Biotechnol. 2016, 7, 279.

31. Kristjanson, P.; Neufeldt, H.; Gassner, A.; Mango, J.; Kyazze, F.B.; Desta, S.; Sayula, G.; Thiede, B.; Forch, W.; Thornton, P.K.; et al. Are food insecure smallholder households making changes in their farming practices? Evidence from East Africa. Food Secur. 2012, 4, 381-397. [CrossRef]

32. Lana, M.A.; Eulenstein, F.; Schlindwein, S.; Guevara, E.; Meira, S.; Wurbs, A.; Sieber, S.; Svoboda, N.; Bonatti, M. Regionalization of climate scenarios impacts on maize production and the role of cultivar and planting date as an adaptation strategy. Reg. Environ. Chang. 2016, 16, 1319-1331. [CrossRef]

33. Liu, S.; Yang, J.Y.; Zhang, X.Y.; Drury, C.F.; Reynolds, W.D.; Hoogenboom, G. Modelling crop yield, soil water content and soil temperature for a soybean-maize rotation under conventional and conservation tillage systems in Northeast China. Agric. Water Manag. 2013, 123, 32-44. [CrossRef]

34. Gautam, S.; Mbonimpa, E.G.; Kumar, S.; Bonta, J.V.; Lal, R. Agricultural Policy Environmental eXtender model simulation of climate change impacts on runoff from a small no-till watershed. J. Soil Water Conserv. 2015, 70, 101-109. [CrossRef]

35. Nasim, W.; Ahmad, A.; Beihouchette, H.; Fahad, S.; Hoogenboom, G. Evaluation of the OILCROP-SUN model for sunflower hybrids under different agro-meteorological conditions of Punjab-Pakistan. Field Crops Res. 2016, 188, 17-30. [CrossRef]

36. Nasim, W.; Belhouchette, H.; Ahmad, A.; Habib-ur-Rahman, M.; Jabran, K.; Ullah, K.; Fahad, S.; Shakeel, M.; Hoogenboom, G. Modelling climate change impacts and adaptation strategies for sunflower in Pakistan. Outlook Agric. 2016, 45, 39-45. [CrossRef]

37. Roost, N.; Cai, X.L.; Turral, H.; Molden, D.; Cui, Y.L. Adapting to intersectoral transfers in the Zhanghe Irrigation System, China-Part II: Impacts of in-system storage on water balance and productivity. Agric. Water Manag. 2008, 95, 685-697. [CrossRef]

38. Samuel, M.P.; Satapathy, K.K. Concerted rainwater harvesting technologies suitable for hilly agro-ecosystems of Northeast India. Curr. Sci. 2008, 95, 1130-1132.

39. Das, A.; Munda, G.C.; Thakur, N.S.A.; Yadav, R.K.; Ghosh, P.K.; Ngachan, S.V.; Bujarbaruah, K.M.; Lal, B.; Das, S.K.; Mahapatra, B.K.; et al. Rainwater harvesting and integrated development of agri-horti-livestock-cum-pisciculture in high altitudes for livelihood of Tribal farmers. Indian J. Agric. Sci. 2014, 84, 643-649.

40. Tuppad, P.; Santhi, C.; Wang, X.; Williams, J.R.; Srinivasan, R.; Gowda, P.H. Simulation of conservation practices using the apex model. Appl. Eng. Agric. 2010, 26, 779-794. [CrossRef]

41. Zairi, A.; el Amami, H.; Slatni, A.; Pereira, L.S.; Rodrigues, P.N.; Machado, T. Coping with drought: Deficit irrigation strategies for cereals and field horticultural crops in Central Tunisia. In Tools for Drought Mitigation in Mediterranean Regions; Rossi, G., Cancelliere, A., Pereira, L.S., Oweis, T., Shatanawi, M., Zairi, A., Eds.; Springer: Dordrecht, The Netherlands, 2003; pp. 181-201.

42. Singh, R.; van Dam, J.C.; Feddes, R.A. Water productivity analysis of irrigated crops in Sirsa district, India. Agric. Water Manag. 2006, 82, 253-278. [CrossRef]

43. Koocheki, A.; Seyyedi, S.M.; Eyni, M.J. Irrigation levels and dense planting affect flower yield and phosphorus concentration of saffron corms under semi-arid region of Mashhad, Northeast Iran. Sci. Hortic. 2014, 180, 147-155. [CrossRef] 
44. Zhou, L.F.; Feng, H.; Zhao, Y.; Qi, Z.J.; Zhang, T.B.; He, J.Q.; Dyck, M. Drip irrigation lateral spacing and mulching affects the wetting pattern, shoot-root regulation, and yield of maize in a sand-layered soil. Agric. Water Manag. 2017, 184, 114-123. [CrossRef]

45. Yang, Y.H.; Watanabe, M.; Zhang, X.Y.; Zhang, J.Q.; Wang, Q.X.; Hayashi, S. Optimizing irrigation management for wheat to reduce groundwater depletion in the piedmont region of the Taihang Mountains in the North China Plain. Agric. Water Manag. 2006, 82, 25-44. [CrossRef]

46. Fan, Z.B.; Lin, S.; Zhang, X.M.; Jiang, Z.M.; Yang, K.C.; Jian, D.D.; Chen, Y.Z.; Li, J.L.; Chen, Q.; Wang, J.G. Conventional flooding irrigation causes an overuse of nitrogen fertilizer and low nitrogen use efficiency in intensively used solar greenhouse vegetable production. Agric. Water Manag. 2014, 144, 11-19. [CrossRef]

47. Meng, W.W.; Yu, Z.W.; Zhang, Y.L.; Shi, Y.; Wang, D. Effects of supplemental irrigation on water consumption characteristics and grain yield in different wheat cultivars. Chil. J. Agric. Res. 2015, 75, $216-223$.

48. Bouraima, A.K.; Zhang, W.H.; Wei, C.F. Irrigation water requirements of rice using Cropwat model in Northern Benin. Int. J. Agric. Biol. Eng. 2015, 8, 58-64.

49. Wang, Y.J.; Xie, Z.K.; Malhi, S.S.; Vera, C.L.; Zhang, Y.B.; Wang, J.N. Effects of rainfall harvesting and mulching technologies on water use efficiency and crop yield in the semi-arid Loess Plateau, China. Agric. Water Manag. 2009, 96, 374-382. [CrossRef]

50. Yeboah, S.; Zhang, R.; Cai, L.; Li, L.; Xie, J.; Luo, Z.; Liu, J.; Wu, J. Tillage effect on soil organic carbon, microbial biomass carbon and crop yield in spring wheat-field pea rotation. Plant Soil Environ. 2016, 62, 279-285. [CrossRef]

51. Corbeels, M.; Chirat, G.; Messad, S.; Thierfelder, C. Performance and sensitivity of the DSSAT crop growth model in simulating maize yield under conservation agriculture. Eur. J. Agron. 2016, 76, 41-53. [CrossRef]

52. Baudron, F.; Delmotte, S.; Corbeels, M.; Herrera, J.M.; Tittonell, P. Multi-scale trade-off analysis of cereal residue use for livestock feeding vs. soil mulching in the Mid-Zambezi Valley, Zimbabwe. Agric. Syst. 2015, 134, 97-106. [CrossRef]

53. Nielsen, D.C.; Vigil, M.F. Intensifying a semi-arid dryland crop rotation by replacing fallow with pea. Agric. Water Manag. 2017, 186, 127-138. [CrossRef]

54. Jiang, J.S.; Guo, S.L.; Zhang, Y.J.; Liu, Q.F.; Wang, R.; Wang, Z.Q.; Li, N.N.; Li, R.J. Changes in temperature sensitivity of soil respiration in the phases of a three-year crop rotation system. Soil Tillage Res. 2015, 150, 139-146. [CrossRef]

55. Gozubuyuk, Z.; Sahin, U.; Adiguzel, M.C.; Ozturk, I.; Celik, A. The influence of different tillage practices on water content of soil and crop yield in vetch-winter wheat rotation compared to fallow-winter wheat rotation in a high altitude and cool climate. Agric. Water Manag. 2015, 160, 84-97. [CrossRef]

56. Fernandez-Getino, A.P.; Santin-Montanya, M.I.; Zambrana, E.; de Andres, E.F.; Tenorio, J.L. The response of barley to rainfall and temperature in different tillage and crop rotation systems in semi-arid conditions. Ann. Appl. Biol. 2015, 166, 143-153. [CrossRef]

57. Sarani, M.; Oveisi, M.; Mashhadi, H.R.; Alizade, H.; Gonzalez-Andujar, J.L. Interactions between the tillage system and crop rotation on the crop yield and weed populations under arid conditions. Weed Biol. Manag. 2014, 14, 198-208. [CrossRef]

58. Srinivasarao, C.; Venkateswarlu, B.; Lal, R.; Singh, A.K.; Kundu, S.; Vittal, K.P.R.; Ramachandrappa, B.K.; Gajanan, G.N. Long-term effects of crop residues and fertility management on carbon sequestration and agronomic productivity of groundnut-finger millet rotation on an Alfisol in southern India. Int. J. Agric. Sustain. 2012, 10, 230-244. [CrossRef]

59. Aulakh, M.S.; Manchanda, J.S.; Garg, A.K.; Kumar, S.; Dercon, G.; Nguyen, M.L. Crop production and nutrient use efficiency of conservation agriculture for soybean-wheat rotation in the Indo-Gangetic Plains of Northwestern India. Soil Tillage Res. 2012, 120, 50-60. [CrossRef]

60. Soler, C.M.T.; Bado, V.B.; Traore, K.; Bostick, W.M.; Jones, J.W.; Hoogenboom, G. Soil organic carbon dynamics and crop yield for different crop rotations in a degraded ferruginous tropical soil in a semi-arid region: A simulation approach. J. Agric. Sci. 2011, 149, 579-593. [CrossRef] [PubMed]

61. Gwenzi, W.; Gotosa, J.; Chakanetsa, S.; Mutema, Z. Effects of tillage systems on soil organic carbon dynamics, structural stability and crop yields in irrigated wheat (Triticum aestivum L.)-cotton (Gossypium hirsutum L.) rotation in semi-arid Zimbabwe. Nutr. Cycl. Agroecosyst. 2009, 83, 211-221. [CrossRef] 
62. Malley, Z.J.U.; Kayombo, B.; Willcocks, T.J.; Mtakwa, P.W. Ngoro: An indigenous, sustainable and profitable soil, water and nutrient conservation system in Tanzania for sloping land. Soil Tillage Res. 2004, 77, 47-58. [CrossRef]

63. Mupangwa, W.; Twomlow, S.; Walker, S. Dead level contours and infiltration pits for risk mitigation in smallholder cropping systems of southern Zimbabwe. Phys. Chem. Earth 2012, 47-48, 166-172. [CrossRef]

64. Nyakudya, I.W.; Stroosnijder, L.; Nyagumbo, I. Infiltration and planting pits for improved water management and maize yield in semi-arid Zimbabwe. Agric. Water Manag. 2014, 141, 30-46. [CrossRef]

65. Gheysari, M.; Miriatifi, S.M.; Bannayan, M.; Homaee, M.; Hoogenboom, G. Interaction of water and nitrogen on maize grown for silage. Agric. Water Manag. 2009, 96, 809-821. [CrossRef]

66. Li, W.L.; Li, W.D.; Li, Z.Z. Irrigation and fertilizer effects on water use and yield of spring wheat in semi-arid regions. Agric. Water Manag. 2004, 67, 35-46. [CrossRef]

67. Wen, J.L.; Li, J.S.; Li, Y.F. Response of maize growth and yield to different water and nitrogen schemes on very coarse sandy loam soil under sprinkler irrigation in the semi-arid region of china. Irrig. Drain. 2015, 64, 619-636. [CrossRef]

68. Jia, X.C.; Shao, L.J.; Liu, P.; Zhao, B.Q.; Gu, L.M.; Dong, S.T.; Bing, S.H.; Zhang, J.W.; Zhao, B. Effect of different nitrogen and irrigation treatments on yield and nitrate leaching of summer maize (Zea mays L.) under lysimeter conditions. Agric. Water Manag. 2014, 137, 92-103. [CrossRef]

69. Devkota, K.P.; McDonald, A.J.; Khadka, L.; Khadka, A.; Paudel, G.; Devkota, M. Fertilizers, hybrids, and the sustainable intensification of maize systems in the rainfed mid-hills of Nepal. Eur. J. Agron. 2016, 80, 154-167. [CrossRef]

70. Rezaei, E.E.; Gaiser, T.; Siebert, S.; Ewert, F. Adaptation of crop production to climate change by crop substitution. Mitig. Adapt. Strateg. Glob. Chang. 2015, 20, 1155-1174. [CrossRef]

71. Biederbeck, V.O.; Janzen, H.H.; Campbell, C.A.; Zentner, R.P. Labile soil organic-matter as influenced by cropping practices in an arid environment. Soil Biol. Biochem. 1994, 26, 1647-1656. [CrossRef]

72. Balwinder, S.; Humphreys, E.; Sudhir, Y.; Gaydon, D.S. Options for increasing the productivity of the rice-wheat system of north-west India while reducing groundwater depletion. Part 1. Rice variety duration, sowing date and inclusion of mungbean. Field Crops Res. 2015, 173, 68-80. [CrossRef]

73. Jalota, S.K.; Vashisht, B.B. Adapting. cropping systems to future climate change scenario in three agro-climatic zones of Punjab, India. J. Agrometeorol. 2016, 18, 48-56.

74. Folberth, C.; Gaiser, T.; Abbaspour, K.C.; Schulin, R.; Yang, H. Regionalization of a large-scale crop growth model for sub-Saharan Africa: Model setup, evaluation, and estimation of maize yields. Agric. Ecosyst. Environ. 2012, 151, 21-33. [CrossRef]

75. Waongo, M.; Laux, P.; Kunstmann, H. Adaptation to climate change: The impacts of optimized planting dates on attainable maize yields under rainfed conditions in Burkina Faso. Agric. For. Meteorol. 2015, 205, 23-39. [CrossRef]

76. Nyagumbo, I.; Mkuhlani, S.; Mupangwa, W.; Rodriguez, D. Planting date and yield benefits from conservation agriculture practices across Southern Africa. Agric. Syst. 2017, 150, 21-33. [CrossRef]

77. Nyakudya, I.W.; Stroosnijder, L. Effect of rooting depth, plant density and planting date on maize (Zea mays L.) yield and water use efficiency in semi-arid Zimbabwe: Modelling with AquaCrop. Agric. Water Manag. 2014, 146, 280-296. [CrossRef]

78. Abou-Hadid, A.F. The agro-climate application information system for crop production and protection in Egypt. In Proceedings of the International Symposium on Mediterranean Horticulture: Issues and Prospects; Sansavini, S., Janick, J., Eds.; ISHS Acta Horticulturae: Leuven, Belgium, 2002; pp. 41-51.

79. Sarvari, M.; Futo, Z.; Zsoldos, M. Effect of sowing date and plant density on maize yields in 2001. Novenytermeles 2002, 51, 291-307.

80. Oweis, T.; Hachum, A.; Pala, M. Water use efficiency of winter-sown chickpea under supplemental irrigation in a mediterranean environment. Agric. Water Manag. 2004, 66, 163-179. [CrossRef]

81. Yau, S.K.; Nimah, M.; Farran, M. Early sowing and irrigation to increase barley yields and water use efficiency in Mediterranean conditions. Agric. Water Manag. 2011, 98, 1776-1781. [CrossRef]

82. Moradi, R.; Koocheki, A.; Mahallati, M.N.; Mansoori, H. Adaptation strategies for maize cultivation under climate change in Iran: Irrigation and planting date management. Mitig. Adapt. Strateg. Glob. Chang. 2013, 18, 265-284. [CrossRef] 
83. Al Khamisi, S.A.; Prathapar, S.A.; Ahmed, M. Conjunctive use of reclaimed water and groundwater in crop rotations. Agric. Water Manag. 2013, 116, 228-234. [CrossRef]

84. Ghamarnia, H.; Farmanifard, M. Yield production and water-use efficiency of wheat (Triticum aestivum L.) cultivars under shallow groundwater use in semi-arid region. Arch. Agron. Soil Sci. 2014, 60, 1677-1700.

85. Wu, Y.; Liu, T.X.; Paredes, P.; Duan, L.M.; Pereira, L.S. Water use by a groundwater dependent maize in a semi-arid region of Inner Mongolia: Evapotranspiration partitioning and capillary rise. Agric. Water Manag. 2015, 152, 222-232. [CrossRef]

86. Liu, Z.; Huang, W.C. Drought early warning in irrigation area by integrating surface water and groundwater. Paddy Water Environ. 2015, 13, 145-157. [CrossRef]

87. Wu, X.; Zheng, Y.; Wu, B.; Tian, Y.; Han, F.; Zheng, C.M. Optimizing conjunctive use of surface water and groundwater for irrigation to address human-nature water conflicts: A surrogate modeling approach. Agric. Water Manag. 2016, 163, 380-392. [CrossRef]

88. Brouwer, J.; Fussell, L.K.; Herrmann, L. Soil and crop growth microvariability in the West-African semiarid tropics-A possible risk-reducing factor for subsistence farmers. Agric. Ecosyst. Environ. 1993, 45, 229-238. [CrossRef]

89. Filintas, A.; Dioudis, P.; Prochaska, C. GIS modeling of the impact of drip irrigation, of water quality and of soil's available water capacity on Zea mays L. biomass yield and its biofuel potential. Desalination Water Treat. 2010, 13, 303-319. [CrossRef]

90. Anzai, T.; Kitamura, Y.; Shimizu, K. The influence of seepage from canals and paddy fields on the groundwater level of neighboring rotation cropping fields: A case study from the lower Ili River Basin, Kazakhstan. Paddy Water Environ. 2014, 12, 387-392. [CrossRef]

91. Schmitter, P.; Zwart, S.J.; Danvi, A.; Gbaguidi, F. Contributions of lateral flow and groundwater to the spatio-temporal variation of irrigated rice yields and water productivity in a West-African inland valley. Agric. Water Manag. 2015, 152, 286-298. [CrossRef]

92. Bayu, W.; Rethman, N.F.G.; Hammes, P.S. Effects of tied-ridge, nitrogen fertilizer and cultivar on the yield and nitrogen use efficiency of sorghum in semi-arid Ethiopia. Arch. Agron. Soil Sci. 2012, 58, 547-560. [CrossRef]

93. Bijanzadeh, E.; Emam, Y. Evaluation of assimilate remobilization and yield of wheat cultivars under different irrigation regimes in an arid climate. Arch. Agron. Soil Sci. 2012, 58, 1243-1259. [CrossRef]

94. Haghshenas, A.; Emam, Y.; Ghadiri, H.; Kazemeini, S.A.; Kamgar-Haghighi, A.A. Effect of Mixed Cropping of an Early- and a Middle-ripening Wheat Cultivar on Mitigation of Competition during Post-anthesis Moisture Stress. J. Agric. Sci. Technol. 2013, 15, 491-503.

95. Meena, L.R.; Meena, S.L. Production potential, nutrient uptake, economics and soil properties as influenced by fodder sorghum (Sorghum bicolor) cultivars, nitrogen levels and FYM under semi-arid condition of Rajasthan. Range Manag. Agrofor. 2012, 33, 171-176.

96. Fan, F.; Spiertz, J.H.J.; Han, L.P.; Liu, Z.X.; Xie, G.H. Sweet sorghum performance under irrigated conditions in north-west China: Biomass and its partitioning in inbred and hybrid cultivars at two nitrogen levels. Res. Crops 2013, 14, 459-470.

97. Wang, X.L.; Chen, Y.L.; Zhang, S.Q. Cultivar mixture improved yield and water use efficiency via optimization of root properties and biomass distribution in maize (Zea mays L.). Emir. J. Food Agric. 2017, 29, 264-273. [CrossRef]

98. Patane, C.; Saita, A.; Sortino, O. Comparative Effects of Salt and Water Stress on Seed Germination and Early Embryo Growth in Two Cultivars of Sweet Sorghum. J. Agron. Crop Sci. 2013, 199, 30-37. [CrossRef]

99. Perazzo, A.F.; de Carvalho, G.G.P.; Santos, E.M.; Pinho, R.M.A.; Campos, F.S.; Macedo, C.H.O.; Azevedo, J.A.G.; Tabosa, J.N. Agronomic evaluation of 32 sorghum cultivars in the Brazilian semi-arid region. Rev. Bras. Zootecnia Braz. J. Anim. Sci. 2014, 43, 232-237. [CrossRef]

100. Mourice, S.K.; Rweyemamu, C.L.; Tumbo, S.D.; Amuri, N. Maize Cultivar Specific Parameters for Decision Support System for Agrotechnology Transfer (DSSAT) Application in Tanzania. Am. J. Plant Sci. 2014, 5, 821-833. [CrossRef]

101. Miriti, J.M.; Kironchi, G.; Esilaba, A.O.; Heng, L.K.; Gachene, C.K.K.; Mwangi, D.M. Yield and water use efficiencies of maize and cowpea as affected by tillage and cropping systems in semi-arid Eastern Kenya. Agric. Water Manag. 2012, 115, 148-155. [CrossRef] 
102. Wright, J.P.; Posner, J.L.; Doll, J.D. The effect of tied ridge cultivation on the yield of maize and a maize cowpea relay in the Gambia. Exp. Agric. 1991, 27, 269-279. [CrossRef]

103. Kabanza, A.K.; Rwehumbiza, F.B.R. Assessment of the contribution of tied ridges and farmyard manure application to sorghum production in semi-arid areas of Tanzania. In Advances in Integrated Soil Fertility Management in Sub-Saharan Africa: Challenges and Opportunities; Bationo, A., Waswa, B., Kihara, J., Kimetu, J., Eds.; Springer: Dordrecht, The Netherlands, 2007; pp. 723-729.

104. Araya, A.; Stroosnijder, L. Effects of tied ridges and mulch on barley (Hordeum vulgare) rainwater use efficiency and production in Northern Ethiopia. Agric. Water Manag. 2010, 97, 841-847. [CrossRef]

105. Odunze, A.C.; Mando, A.; Sogbedji, J.; Amapu, I.Y.; Tarfa, B.D.; Yusuf, A.A.; Sunday, A.; Bello, H. Moisture conservation and fertilizer use for sustainable cotton production in the sub-humid Savanna zones of Nigeria. Arch. Agron. Soil Sci. 2012, 58, S190-S194. [CrossRef]

106. Saha, S.; Chakraborty, D.; Sharma, A.R.; Tomar, R.K.; Bhadraray, S.; Sen, U.; Behera, U.K.; Purakayastha, T.J.; Garg, R.N.; Kalra, N. Effect of tillage and residue management on soil physical properties and crop productivity in maize (Zea mays)-Indian mustard (Brassica juncea) system. Indian J. Agric. Sci. 2010, 80, 679-685.

107. Choudhury, S.G.; Srivastava, S.; Singh, R.; Chaudhari, S.K.; Sharma, D.K.; Singh, S.K.; Sarkar, D. Tillage and residue management effects on soil aggregation, organic carbon dynamics and yield attribute in rice-wheat cropping system under reclaimed sodic soil. Soil Tillage Res. 2014, 136, 76-83. [CrossRef]

108. Temesgen, M.; Savenije, H.H.G.; Rockstrom, J.; Hoogmoed, W.B. Assessment of strip tillage systems for maize production in semi-arid Ethiopia: Effects on grain yield, water balance and water productivity. Phys. Chem. Earth 2012, 47-48, 156-165. [CrossRef]

109. Verhulst, N.; Sayre, K.D.; Vargas, M.; Crossa, J.; Deckers, J.; Raes, D.; Goyaerts, B. Wheat yield and tillage-straw management system $\times$ year interaction explained by climatic co-variables for an irrigated bed planting system in northwestern Mexico. Field Crops Res. 2011, 124, 347-356. [CrossRef]

110. Verhulst, N.; Nelissen, V.; Jespers, N.; Haven, H.; Sayre, K.D.; Raes, D.; Deckers, J.; Govaerts, B. Soil water content, maize yield and its stability as affected by tillage and crop residue management in rainfed semi-arid highlands. Plant Soil 2011, 344, 73-85. [CrossRef]

111. Malhi, S.S.; Soon, Y.K.; Brandt, S. Effect of growing season rainfall and tillage on the uptake and recovery of (15)N-labelled urea fertilizer by spring wheat in a semi-arid environment. Can. J. Soil Sci. 2009, 89, 403-411. [CrossRef]

112. Iqbal, M.; Anwar-Ul-Hassan; Lal, R. Nutrient content of maize and soil organic matter status under various tillage methods and farmyard manure levels. Acta Agric. Scand. Sect. B Soil Plant Sci. 2007, 57, 349-356.

113. Iqbal, M.; Anwar-Ul-Hassan; Ibrahim, M. Effects of tillage systems and mulch on soil physical quality parameters and maize (Zea mays L.) yield in semi-arid Pakistan. Biol. Agric. Hortic. 2008, 25, 311-325. [CrossRef]

114. Iqbal, M.; Anwar-Ul-Hassan; van Es, H.M. Influence of Residue Management and Tillage Systems on Carbon Sequestration and Nitrogen, Phosphorus, and Potassium Dynamics of Soil and Plant and Wheat Production in Semi-arid Region. Commun. Soil Sci. Plant Anal. 2011, 42, 528-547. [CrossRef]

115. Scopel, E.; da Silva, F.A.M.; Corbeels, M.; Affholder, F.O.; Maraux, F. Modelling crop residue mulching effects on water use and production of maize under semi-arid and humid tropical conditions. Agronomie 2004, 24, 383-395. [CrossRef]

116. Mugabe, F.T.; Chitata, T.; Kashaigili, J.; Chagonda, I. Modelling the effect of rainfall variability, land use change and increased reservoir abstraction on surface water resources in semi-arid southern Zimbabwe. Phys. Chem. Earth 2011, 36, 1025-1032. [CrossRef]

117. Shao, H.; Baffaut, C.; Gao, J.E.; Nelson, N.O.; Janssen, K.A.; Pierzynski, G.M.; Barnes, P.L. Development and application of algorithms for simulating terraces within swat. Trans. Asabe 2013, 56, 1715-1730.

118. Biazin, B.; Stroosnijder, L. To tie or not to tie ridges for water conservation in Rift Valley drylands of Ethiopia. Soil Tillage Res. 2012, 124, 83-94. [CrossRef]

119. Iqbal, S.; Guber, A.K.; Khan, H.Z. Estimating nitrogen leaching losses after compost application in furrow irrigated soils of Pakistan using HYDRUS-2D software. Agric. Water Manag. 2016, 168, 85-95. [CrossRef] 
120. Ngugi, L.W.; Rao, K.P.C.; Oyoo, A.; Kwena, K. Opportunities for Coping with Climate Change and Variability through Adoption of Soil and Water Conservation Technologies in Semi-arid Eastern Kenya. In Adapting African Agriculture to Climate Change: Transforming Rural Livelihoods; Filho, W.L., Esilaba, A.O., Rao, K.P.C., Sridhar, G., Eds.; Springer: Cham, Switzerland, 2015; pp. 149-157.

121. Shamudzarira, Z.; Robertson, M.J. Simulating response of maize to nitrogen fertilizer in semi-arid Zimbabwe. Exp. Agric. 2002, 38, 79-96. [CrossRef]

122. Kisaka, M.O.; Mucheru-Muna, M.; Ngetich, F.K.; Mugwe, J.N.; Mugendi, D.N.; Mairura, F.; Muriuki, J. Using apsim-model as a decision-support-tool for long-term integrated-nitrogen-management and maize productivity under semi-arid conditions in Kenya. Exp. Agric. 2016, 52, 279-299. [CrossRef]

123. Ahmed, M.; Aslam, M.A.; Ul, H.F.; Asif, M.; Hayat, R. Use of APSIM to Model Nitrogen Use Efficiency of Rain-fed Wheat. Int. J. Agric. Biol. 2014, 16, 461-470.

124. Gaiser, T.; de Barros, I.; Lange, F.M.; Williams, J.R. Water use efficiency of a maize/cowpea intercrop on a highly acidic tropical soil as affected by liming and fertilizer application. Plant Soil 2004, 263, 165-171. [CrossRef]

125. Azizian, A.; Sepaskhah, A.R.; Zand-Parsa, S. Modification of a maize simulation model under different water, nitrogen and salinity levels. Int. J. Plant Prod. 2015, 9, 609-632.

126. Anwar, M.R.; Takahashi, S.; Itoh, S.; Nakatsuji, T. Modeling yield and grain protein of Japanese wheat by DSSAT cropping system model. In Plant Growth Modeling and Applications; Hu, B.G., Jaeger, M., Eds.; Liama, Chinese Agricultural University: Beijing, China, 2003; pp. 312-320.

127. Jagtap, S.S.; Abamu, F.J. Matching improved maize production technologies to the resource base of farmers in a moist savanna. Agric. Syst. 2003, 76, 1067-1084. [CrossRef]

128. Liu, H.L.; Yang, J.Y.; Drury, C.F.; Reynolds, W.D.; Tan, C.S.; Bai, Y.L.; He, P.; Jin, J.; Hoogenboom, G. Using the DSSAT-CERES-Maize model to simulate crop yield and nitrogen cycling in fields under long-term continuous maize production. Nutr. Cycl. Agroecosyst. 2011, 89, 313-328. [CrossRef]

129. Gerardeaux, E.; Giner, M.; Ramanantsoanirina, A.; Dusserre, J. Positive effects of climate change on rice in Madagascar. Agron. Sustain. Dev. 2012, 32, 619-627. [CrossRef]

130. Jeong, H.; Jang, T.; Seong, C.; Park, S. Assessing nitrogen fertilizer rates and split applications using the DSSAT model for rice irrigated with urban wastewater. Agric. Water Manag. 2014, 141, 1-9. [CrossRef]

131. Rezaei, E.E.; Gaiser, T.; Siebert, S.; Sultan, B.; Ewert, F. Combined impacts of climate and nutrient fertilization on yields of pearl millet in Niger. Eur. J. Agron. 2014, 55, 77-88. [CrossRef]

132. Abedinpour, M.; Sarangi, A.; Rajput, T.B.S.; Singh, M.; Pathak, H.; Ahmad, T. Performance evaluation of AquaCrop model for maize crop in a semi-arid environment. Agric. Water Manag. 2012, 110, 55-66. [CrossRef]

133. Heng, L.K.; Asseng, S.; Mejahed, K.; Rusan, M. Optimizing wheat productivity in two rain-fed environments of the West Asia-North Africa region using a simulation model. Eur. J. Agron. 2007, 26, 121-129. [CrossRef]

134. Soltani, A.; Meinke, H.; de Voil, P. Assessing linear interpolation to generate daily radiation and temperature data for use in crop simulations. Eur. J. Agron. 2004, 21, 133-148. [CrossRef]

135. Toumi, J.; Er-Raki, S.; Ezzahar, J.; Khabba, S.; Jarlan, L.; Chehbouni, A. Performance assessment of AquaCrop model for estimating evapotranspiration, soil water content and grain yield of winter wheat in Tensift $\mathrm{Al}$ Haouz (Morocco): Application to irrigation management. Agric. Water Manag. 2016, 163, 219-235. [CrossRef]

136. Abrha, B.; Delbecque, N.; Raes, D.; Tsegay, A.; Todorovic, M.; Heng, L.; Vanutrecht, E.; Geerts, S.; Garcia-Vila, M.; Deckers, S. Sowing strategies for barley (Hordeum vulgare L.) Based on modelled yield response to water with aquacrop. Exp. Agric. 2012, 48, 252-271. [CrossRef]

137. Alemaw, B.F.; Chaoka, T.R.; Totolo, O. Soil moisture modeling and application in agricultural water management. In Proceedings of the IASTED International Conference on Environmentally Sound Technology in Water Resources Management: Science and Technology for Development in the 21st Century; Totolo, O., Ed.; ACTA Press: Calgary, AB, Canada, 2006; pp. 120-125.

138. Hurtado, S.M.C.; Paglis, C.M.; von Pinho, R.G. Ceres-Maize model efficiency in corn yield prediction within spatial variable areas. Cienc. Agrotecnol. 2005, 29, 1153-1160. [CrossRef]

139. Al-Bakri, J.; Suleiman, A.; Abdulla, F.; Ayad, J. Potential impact of climate change on rainfed agriculture of a semi-arid basin in Jordan. Phys. Chem. Earth 2011, 36, 125-134. [CrossRef] 
140. Sandhu, S.S.; Prabhjyot, K.; Tripathi, P.; Patel, S.R.; Prasad, R.; Solanki, N.S.; Kumar, R.; Singh, C.B.; Dubey, A.P.; Rao, V.U.M. Effect of intra-seasonal temperature on wheat at different locations of India: A study using CERES-Wheat model. J. Agrometeorol. 2016, 18, 222-233.

141. MacCarthy, D.S.; Adiku, S.G.K.; Freduah, B.S.; Gbefo, F.; Kamara, A.Y. Using CERES-Maize and ENSO as Decision Support Tools to Evaluate Climate Sensitive Farm Management Practices for Maize Production in the Northern Regions of Ghana. Front. Plant Sci. 2017, 8, 31. [CrossRef] [PubMed]

142. Bacon, S.A.; Mau, R.; Neto, F.M.; Williams, R.L.; Turner, N.C. Effect of climate warming on maize production in Timor-Leste: Interaction with nitrogen supply. Crop Pasture Sci. 2016, 67, 156-166.

143. Manfreda, S.; Scanlon, T.M.; Caylor, K.K. On the importance of accurate depiction of infiltration processes on modelled soil moisture and vegetation water stress. Ecohydrology 2010, 3, 155-165. [CrossRef]

144. Prucha, B.; Graham, D.; Watson, M.; Avenant, M.; Esterhuyse, S.; Joubert, A.; Kemp, M.; King, J.; le Roux, P.; Redelinghuys, N.; et al. MIKE-SHE integrated groundwater and surface water model used to simulate scenario hydrology for input to DRIFT-ARID: The Mokolo River case study. Water SA 2016, 42, 384-398. [CrossRef]

145. White, J.W.; Hoogenboom, G.; Kimball, B.A.; Wall, G.W. Methodologies for simulating impacts of climate change on crop production. Field Crops Res. 2011, 124, 357-368. [CrossRef]

146. Critchley, W.; Reij, C.; Seznec, A. Water Harvesting for Plant Production, Volume II: Case Studies and Conclusions for Sub-Saharan Africa; World Bank Technical Paper No. 157; Africa Technical Department Series 134; The World Bank: Washington, DC, USA, 1992.

147. Nyamangara, J.; Nyagumbo, I. Interactive effects of selected nutrient resources and tied-ridging on plant growth performance in a semi-arid smallholder farming environment in central Zimbabwe. Nutr. Cycl. Agroecosyst. 2010, 88, 103-109. [CrossRef]

148. Patrick, C.; Kechavarzi, C.; James, I.T.; O’Dogherty, M.; Godwin, R.J. Developing reservoir tillage technology for semi-arid environments. Soil Use Manag. 2007, 23, 185-191. [CrossRef]

149. Hunink, J.E.; Droogers, P.; Kauffman, S.; Mwaniki, B.M.; Bouma, J. Quantitative simulation tools to analyze up- and downstream interactions of soil and water conservation measures: Supporting policy making in the Green Water Credits program of Kenya. J. Environ. Manag. 2012, 111, 187-194. [CrossRef] [PubMed]

150. Biazin, B.; Sterk, G.; Temesgen, M. Participatory Planning of Appropriate Rainwater Harvesting and Management Techniques in the Central Rift Valley Dry Lands of Ethiopia. Environ. Nat. Resour. Res. 2014, 4. [CrossRef]

151. Twomlow, S.; Rohrbach, D.; Dimes, J.; Rusike, J.; Mupangwa, W.; Ncube, B.; Hove, L.; Moyo, M.; Mashingaidze, N.; Mahposa, P. Micro-dosing as a pathway to Africa's Green Revolution: Evidence from broad-scale on-farm trials. Nutr. Cycl. Agroecosyst. 2010, 88, 3-15. [CrossRef]

152. Sankar, G.R.M.; Sharma, K.L.; Dhanapal, G.N.; Shankar, M.A.; Mishra, P.K.; Venkateswarlu, B.; Grace, J.K. Influence of Soil and Fertilizer Nutrients on Sustainability of Rainfed Finger Millet Yield and Soil Fertility in Semi-arid Alfisols. Commun. Soil Sci. Plant Anal. 2011, 42, 1462-1483. [CrossRef]

153. Tan, Z.X.; Lal, R.; Wiebe, K.D. Global soil nutrient depletion and yield reduction. J. Sustain. Agric. 2005, 26, 123-146. [CrossRef]

154. Wickama, J.; Okoba, B.; Sterk, G. Effectiveness of sustainable land management measures in West Usambara highlands, Tanzania. Catena 2014, 118, 91-102. [CrossRef]

155. Gessesse, B.; Bewket, W.; Brauning, A. Model-Based Characterization and Monitoring of Runoff and Soil Erosion in Response to Land Use/land Cover Changes in the Modjo Watershed, Ethiopia. Land Degrad. Dev. 2015, 26, 711-724. [CrossRef]

156. Bationo, A.; Mokwunye, A.U. Alleviating soil fertility constraints to increased crop production in West Africa-The experience in the Sahel. Fertil. Res. 1991, 29, 95-115. [CrossRef]

157. Mashingaidze, N.; Belder, P.; Twomlow, S.; Hove, L.; Moyo, M. Improving maize (Zea mays L.) performance in semi-arid zimbabwe through micro-dosing with ammonium nitrate tablets. Exp. Agric. 2013, 49, 179-196. [CrossRef]

158. Ibrahim, A.; Abaidoo, R.C.; Fatondji, D.; Opoku, A. Integrated use of fertilizer micro-dosing and Acacia tumida mulching increases millet yield and water use efficiency in Sahelian semi-arid environment. Nutr. Cycl. Agroecosyst. 2015, 103, 375-388. [CrossRef] 
159. Ibahim, A.; Pasternak, D.; Fatondji, D. Impact of depth of placement of mineral fertilizer micro-dosing on growth, yield and partial nutrient balance in pearl millet cropping system in the Sahel. J. Agric. Sci. 2015, 153, 1412-1421. [CrossRef]

160. Ibrahim, A.L.I.; Abaidoo, R.C.; Fatondji, D.; Opoku, A. Determinants of Fertilizer Microdosing-Induced Yield Increment of Pearl Millet on an Acid Sandy Soil. Exp. Agric. 2015, 52, 562-578. [CrossRef]

161. ICRISAT. Fertilizer-Microdosing: Boosting Production in Unproductive Lands; Institute for Semi-Arid Tropics: Patancheru, India, 2009.

162. Bielders, C.L.; Gerard, B. Millet response to microdose fertilization in south-western Niger: Effect of antecedent fertility management and environmental factors. Field Crops Res. 2015, 171, 165-175. [CrossRef]

163. Lamers, J.P.A.; Bruentrup, M.; Buerkert, A. Financial performance of fertilization strategies for sustainable soil fertility management in Sudano-Sahelian West Africa. 2: Profitability of long-term capital investments in rockphosphate. Nutr. Cycl. Agroecosyst. 2015, 102, 149-165. [CrossRef]

164. Bagayoko, M.; Maman, N.; Palé, S.; Sirifi, S.; Taonda, S.J.B.; Traore, S.; Mason, S.C. Microdose and N and P fertilizer application rates for pearl millet in West Africa. Afr. J. Agric. Res. 2011, 6, 1141-1150.

165. Kijazi, A.L.; Reason, C.J.C. Analysis of the 1998 to 2005 drought over the northeastern highlands of Tanzania. Clim. Res. 2009, 38, 209-223. [CrossRef]

166. Flaounas, E.; Bastin, S.; Janicot, S. Regional climate modelling of the 2006 West African monsoon: Sensitivity to convection and planetary boundary layer parameterisation using WRF. Clim. Dyn. 2011, 36, 1083-1105. [CrossRef]

167. Recha, C.W.; Makokha, G.L.; Traore, P.S.; Shisanya, C.; Lodoun, T.; Sako, A. Determination of seasonal rainfall variability, onset and cessation in semi-arid Tharaka district, Kenya. Theor. Appl. Climatol. 2012, 108, 479-494. [CrossRef]

168. Sacks, W.J.; Deryng, D.; Foley, J.A.; Ramankutty, N. Crop planting dates: An analysis of global patterns. Glob. Ecol. Biogeogr. 2010, 19, 607-620. [CrossRef]

169. Nasim, W.; Ahmad, A.; Wajid, S.A.; Usman, M.; Hussain, A.; Khaliq, T.; Sultana, S.R.; Muddasir, M.A.; Ahmad, S. Modeling the Effect of Climate Change on Sowing Dates, Yield and Yield Components in Various Wheat Cultivars under Different Agro-ecological Zones of Punjab-Pakistan. In Progress in Environmental Science and Technology, Vol. II, Parts A and B; Li, S.C., Wang, Y.J., Cao, F.X., Huang, P., Zhang, Y., Eds.; Science Press, Cop.: Beijing, China, 2009; pp. 69-74.

170. Kalita, H.; Bora, P.C.; Debnath, M.C. Effect of sowing date and tillage on soil properties, nutrient uptake and yield of linseed (Linum usitatissimum) grown in winter rice (Oryza sativa)-fallows. Indian J. Agron. 2005, 50, 70-72.

171. Bashir, M.U.; Akbar, N.; Iqbal, A.; Zaman, H. Effect of different sowing dates on yield and yield components of direct seeded coarse rice (Oryza sativa L.). Pak. J. Agric. Sci. 2010, 47, 361-365.

172. Futo, Z.; Sarvari, M. Effect of sowing date on the yield of maize (Zea mays L.) in different years. Novenytermeles 2003, 52, 543-558.

173. Yamusa, A.M.; Abubakar, I.U.; Falaki, A.M. Rainfall Variability and Crop Production in the Northern-Western Semi-arid Zone of Nigeria. J. Soil Sci. Environ. Manag. 2015, 6, 125-131.

174. Almodares, A.; Darany, S.M.M. Effects of planting date and time of nitrogen application on yield and sugar content of sweet sorghum. J. Environ. Biol. 2006, 27, 601-605. [PubMed]

175. Teetor, V.H.; Duclos, D.V.; Wittenberg, E.T.; Young, K.M.; Chawhuaymak, J.; Riley, M.R.; Ray, D.T. Effects of planting date on sugar and ethanol yield of sweet sorghum grown in Arizona. Ind. Crops Prod. 2011, 34, 1293-1300. [CrossRef]

176. Nafchi, M.A.M.; Golparvar, A.R. Effect of planting dates on protein percentage and yield components of sorghum cultivars grown in Isfahan province of Iran. Res. Crops 2012, 13, 1023-1025.

177. Akossou, A.Y.J.; Attakpa, E.Y.; Fonton, N.H.; Sinsin, B.; Bosma, R.H. Spatial and temporal analysis of maize (Zea mays) crop yields in Benin from 1987 to 2007. Agric. For. Meteorol. 2016, 220, 177-189. [CrossRef]

178. Rowe, E.C.; van Wijk, M.T.; de Ridder, N.; Giller, K.E. Nutrient allocation strategies across a simplified heterogeneous African smallholder farm. Agric. Ecosyst. Environ. 2006, 116, 60-71. [CrossRef]

179. Jones, J.W.; Keating, B.A.; Porter, C.H. Approaches to modular model development. Agric. Syst. 2001, 70 , 421-443. [CrossRef] 
180. Ahmed, M.; Akram, M.N.; Asim, M.; Aslam, M.; Hassan, F.U.; Higgins, S.; Stockle, C.O.; Hoogenboom, G. Calibration and validation of APSIM-Wheat and CERES-Wheat for spring wheat under rainfed conditions: Models evaluation and application. Comput. Electron. Agric. 2016, 123, 384-401. [CrossRef]

181. Brilli, L.; Bechini, L.; Bindi, M.; Carozzi, M.; Cavalli, D.; Conant, R.; Dorich, C.D.; Doro, L.; Ehrhardt, F.; Farina, R.; et al. Review and analysis of strengths and weaknesses of agro-ecosystem models for simulating C and N fluxes. Sci. Total Environ. 2017, 598, 445-470. [CrossRef] [PubMed]

182. Keating, B.A.; Carberry, P.S.; Hammer, G.L.; Probert, M.E.; Robertson, M.J.; Holzworth, D.; Huth, N.I.; Hargreaves, J.N.G.; Meinke, H.; Hochman, Z.; et al. An overview of APSIM, a model designed for farming systems simulation. Eur. J. Agron. 2003, 18, 267-288. [CrossRef]

183. Steduto, P.; Hsiao, T.C.; Raes, D.; Fereres, E. AquaCrop-The FAO Crop Model to Simulate Yield Response to Water: I. Concepts and Underlying Principles. Agron. J. 2009, 101, 426-437. [CrossRef]

184. Hsiao, T.C.; Heng, L.; Steduto, P.; Rojas-Lara, B.; Raes, D.; Fereres, E. AquaCrop-The FAO Crop Model to Simulate Yield Response to Water: III. Parameterization and Testing for Maize. Agron. J. 2009, 101, 448-459. [CrossRef]

185. Raes, D.; Steduto, P.; Hsiao, T.C.; Fereres, E. AquaCrop-The FAO Crop Model to Simulate Yield Response to Water: II. Main Algorithms and Software Description. Agron. J. 2009, 101, 438-447. [CrossRef]

186. Araya, A.; Habtu, S.; Hadgu, K.M.; Kebede, A.; Dejene, T. Test of AquaCrop model in simulating biomass and yield of water deficient and irrigated barley (Hordeum vulgare). Agric. Water Manag. 2010, 97, 1838-1846. [CrossRef]

187. Wellens, J.; Raes, D.; Traore, F.; Denis, A.; Djaby, B.; Tychon, B. Performance assessment of the FAO AquaCrop model for irrigated cabbage on farmer plots in a semi-arid environment. Agric. Water Manag. 2013, 127, 40-47. [CrossRef]

(C) 2018 by the authors. Licensee MDPI, Basel, Switzerland. This article is an open access article distributed under the terms and conditions of the Creative Commons Attribution (CC BY) license (http:/ / creativecommons.org/licenses/by/4.0/). 